\title{
GEOMORPHOLOGICAL EVIDENCE OF TECTONIC ACTIVITY OF THE MARIÁNSKÉ LÁZNĚ FAULT (CZECH REPUBLIC) AND ITS INFLUENCE ON STREAM NETWORK EVOLUTION
}

\author{
Jan FLAŠAR ${ }^{1,2) *}$ and Petra ŠTĚPANČÍKOVÁ ${ }^{1)}$ \\ 1) Institute of Rock Structure and Mechanics, Czech Academy of Sciences, v. v. i., V Holešovičkách 94/41, 182 09 Prague 8, Czech Republic \\ ${ }^{2)}$ Institute of Geology and Palaeontology, Faculty of Science, Charles University, Albertov 6, 12843 Prague 20, Czech Republic
}

*Corresponding author's e-mail: flasar@irsm.cas.cz

\begin{tabular}{|c|c|}
\hline ARTICLE INFO & ABSTRACT \\
\hline Article history: & \multirow{10}{*}{$\begin{array}{l}\text { The Mariánské Lázně Fault (western Bohemia, CZE) is a morphologically, geologically and } \\
\text { tectonically prominent structure with that is } 150 \mathrm{~km} \text { long with an NNW-SSE orientation. Its } \\
\text { tectonic activity, especially in the NW part and in the neighbouring Cheb basin, is well known and } \\
\text { has been proven by present-day earthquake swarms, mantle-derived } \mathrm{CO}_{2} \text { emanations, geophysical } \\
\text { and paleoseismological research. It seems that other parts of the MLF (especially segments of } \\
\text { NNW-SSE and N-S orientation) might also have been active during the Pleistocene, possible even } \\
\text { in the Holocene. This study provides a robust set of morphometric analyses - mountain-front } \\
\text { sinuosity, basin asymmetry, longitudinal stream profiles, SL-index, which assesses the possibility } \\
\text { of recent tectonic activity. The results suggest that the activity of the central and southern part of } \\
\text { the MLF could have been very young. A reconstruction of the evolution of the stream network of } \\
\text { the Mže River, as a result of different timing of the activity of particular segments of the MLF, is } \\
\text { also put forward. The first ideas about the evolution of terrain morphology and the stream network } \\
\text { are proposed by this study, however subsequent field research (geophysics, paleoseismology) } \\
\text { could prove and date the tectonic activity. The delineation of segments with young activity may } \\
\text { also have a great implication for seismic hazard assessment. }\end{array}$} \\
\hline Received 10 September 2021 & \\
\hline Accepted 16 November 2021 & \\
\hline Available online 25 November 2021 & \\
\hline Keywords: & \\
\hline Neotectonics & \\
\hline Mountain front sinuosity & \\
\hline Basin asymmetry & \\
\hline Stream network & \\
\hline Bohemian Massif & \\
\hline
\end{tabular}

\section{INTRODUCTION}

The Mariánské Lázně Fault (MLF) is a structure in western Bohemia (Czech Republic), which is about $150 \mathrm{~km}$ long and has a prevailing orientation of NNW-SSE (see Fig. 1). Its prominence can be seen both in the geology and terrain morphology (Fig. 1 and Fig. 2). The fault itself was formed during the Variscan orogeny 380 - 300 Ma (Pitra et al., 1999) and it separates the main geological units building the Bohemian Massif - Moldanubian, Saxothuringian and Teplá-Barrandian (Fig. 1). The fault was reactivated several times during the Cenozoic, the last reactivation is of Neogene age and persists to this day (Švancara et al., 2008; Fischer et al., 2012). It controls significant effects in the terrain morphology such as a mountain front fault scarp that is up to $300 \mathrm{~m}$ high. The study area is also famous for its Pleistocene volcanic activity (Ulrych et al., 2011, 2013), mineral springs, mantlederived $\mathrm{CO}_{2}$ emanations (Fischer et al., 2017) and the present-day earthquake swarm activity which are still observed (Fischer et al., 2014; Jakoubková et al., 2017; Štěpančíková et al., 2019). Due to these manifestations, the NW part of the MLF is considered to be the youngest as concerns tectonic activity (Štěpančíková et al., 2019). The age of tectonic activity along the rest of the MLF has not been studied in detail yet, but it is considered to be of Miocene-Pliocene age (Špičáková et al., 2000).

In this study morphometric methods were used (mountain front sinuosity, basin asymmetry, water stream longitudinal profiles, stream-length index) to evaluate the intensity and possible relative age of the tectonic activity along the MLF. The results suggest that the activity could have been younger than Miocene-Pliocene - possibly Pleistocene - and most intensive in the central part of the MLF. This uneven tectonic activity, mainly uplift, in particular segments of the MLF could have influenced the evolution of the local stream network. Here a possible reconstruction of the stream network evolution is put forward.

\section{GEOLOGICAL AND GEOMORPHOLOGICAL SETTING}

\subsection{GEOLOGICAL SETTING}

The Mariánské Lázně Fault is a tectonic structure, which is located in the western part of the Bohemian massif in the Czech Republic (for location see Fig. 2). The MLF limits several geological units which have often undergone different geological processes. Therefore, their geological history and lithological structure is very variable (see Fig. 1). There is the Saxothuringian unit in the NW, the 


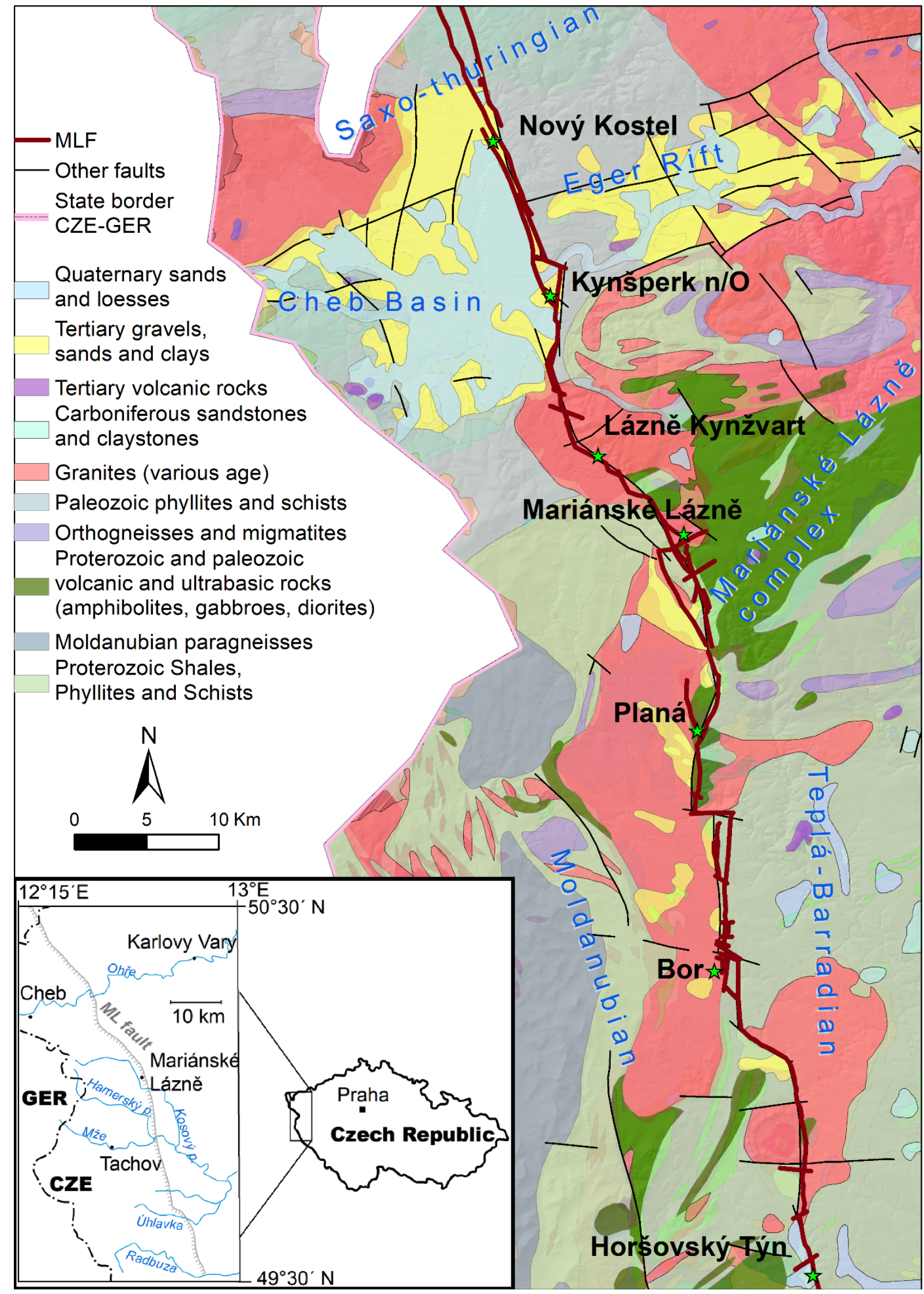

Fig. 1 Simplified geological map of the surroundings of the MLF (based on Zoubek, 1963; Vejnar et al., 1978; Vejnar et al., 1978b; Vejnar et al., 1980; Mahel et al., 1984; Müller et al., 1998; Seifert et al., 1998; Adamová et al., 2001). 


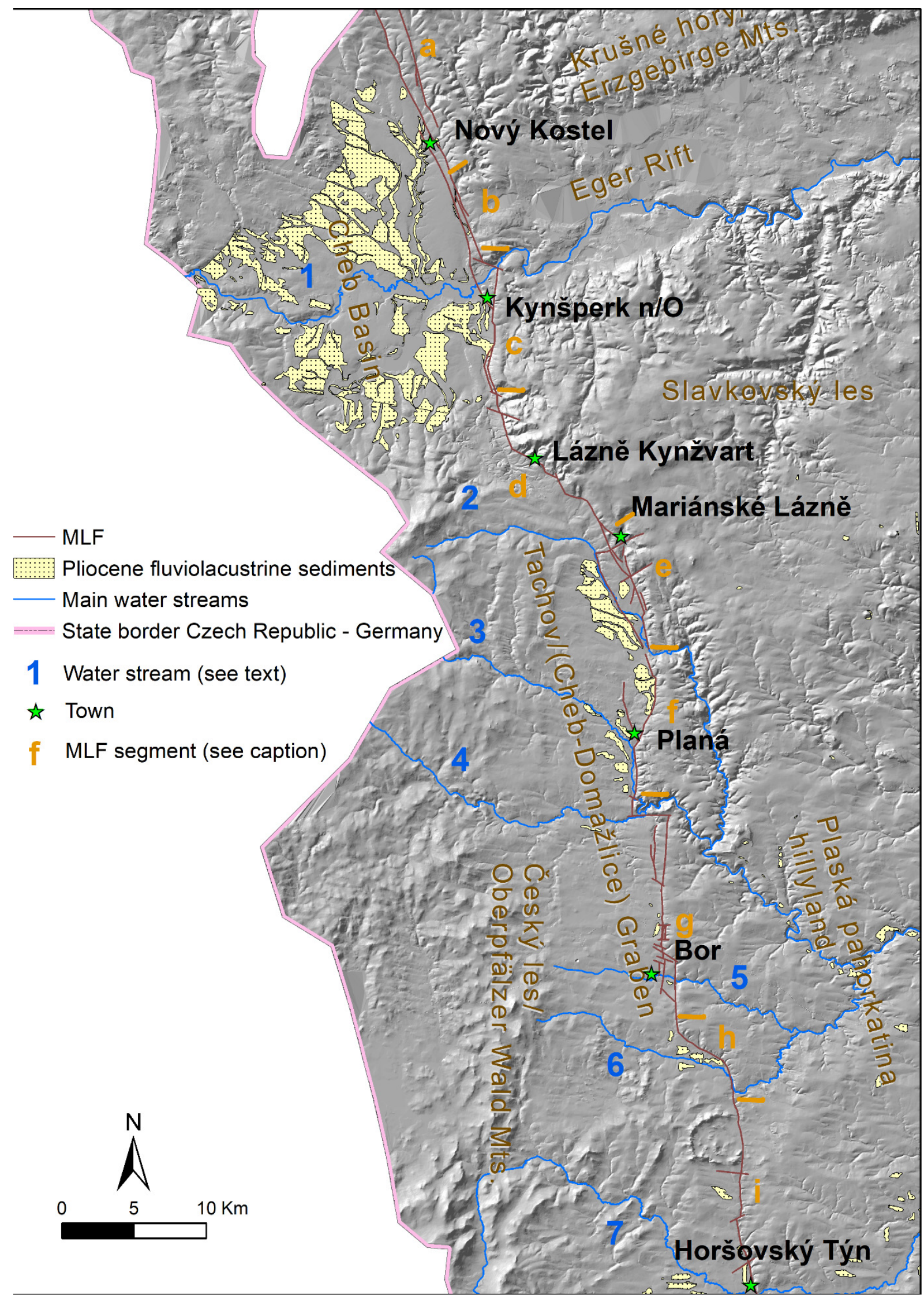

Fig. 2 Terrain overview map of the MLF. Names of the streams: 1 - Ohře, 2 - Kosový, 3 - Hamerský, 4 - Mže, 5 - Výrovský, 6 - Úhlavka, 7 - Radbuza. Please note the coding of the MLF segments by letters (further used through the text). 
Moldanubian unit in the $\mathrm{W}$ and $\mathrm{S}$, the TepláBarrandian unit in the eastern part of the study area and the Mariánské Lázně complex between those units. Some of these crystalline rocks can be overlaid by the tertiary sedimentary units of the Cheb basin (Mlčoch and Skácelová, 2009).

The Saxothuringian crystalline rocks are present along the NW part of the MLF and they also underlay the sedimentary infill of the Cheb basin. These rocks are originally of Proterozoic and Cambrian age; however, they were intensively metamorphosed during the Variscan orogeny, 360 - 330 Ma (Mlčoch and Konopásek, 2010). Paragneisses, schists and orthogneisses are the most frequent rock types in this unit. However less metamorphosed phyllites of Ordovician age can also be found, especially along the fault in the segments $a$ and $b$ of the MLF (Fig. 2; Chlupáč et al., 2002). The Mariánské Lázně complex is a specific lithological unit of highly metamorphosed rocks, which have probably infilled the suture between the Saxothuringian unit and the Teplá-Barradian unit - the two former microcontinents amalgamated during the Variscan orogeny (Mlčoch and Konopásek, 2010). It is composed of mafic and ultramafic rocks: serpentinized peridotite on the basement and sets of amphibolites, eclogites and metagabbros in the upper part (Cháb et al., 2008).

The Teplá-Barrandian unit is less affected by Variscan metamorphosis than the others, however, the parts along the MLF are more intensively metamorphosed than the rest of this unit as the intensity of metamorphosis rises towards the NW. Phyllites, schists and paragneisses can be found along the fault (Chlupáč et al., 2002).

The Moldanubian unit is composed mostly of Variscan metamorphosed rocks like paragneisses, orthogneisses and migmatites. The granitic intrusions are also presented in the study area of pre-Variscan or Variscan age (Cháb et al., 2008).

The MLF bounds the Cheb basin in the NW, which is a half-graben and originated on the crossing of distinct tectonic features: the ENE trending Eger Rift and Cheb-Domažlice Graben (NNW-SSE). The thickest sedimentary infill (up to $400 \mathrm{~m}$ ) of the basin is located in its eastern part controlled by the MLF. The oldest deposits in the basin involve sands, gravels and clays of upper Eocene age (the Starosedelské and Novosedelské Formations) overlaid by sets of coal seams, clays, sands and volcanoclastic (Oligocene and Miocene Sokolov Formation; Špičáková et al. (2000)). The uppermost part of the Miocene deposits is represented by the Cypris Formation, which contains typical greenish clays and claystones (Chlupáč et al., 2002). The Vildštejn Formation of Pliocene/Pleistocene age is the youngest member of the basin's sedimentary infill. This formation is composed of fluviolacustrine sands, gravels and clays and it is not present only in the Cheb basin, but also in several relicts in the Cheb-Domažlice Graben along the MLF (Pešek, 1972; Teodoridis et al., 2017).

\subsection{GEOMORPHOLOGICAL SETTING}

The Mariánské Lázně Fault (MLF) is a NNWSSE trending, morphologically prominent structure, more than $150 \mathrm{~km}$ in length (see Fig. 2). According to Pitra et al. (1999) the fault zone originated in the lateVariscan (380-300 Ma) as a normal fault with a dextral component. The normal character of the fault zone controlled the formation of the Cheb basin from the late Eocene until the Pliocene (Špičáková et al., 2000). However, the MLF is remarkable mainly due to its Quaternary activity. During the Pleistocene, the wider area of the MLF also witnessed the latest volcanic processes in the Bohemian Massif - the activity of the Komorní Hůrka and Železná Hůrka volcanoes and Mýtina maar (e.g. Ulrych et al., 2011, 2013). Balatka et al. (2019) inferred the tectonic uplift along the MLF (10-15 m) also from the truncated Pleistocene fluvial terraces of the Ohře River in the Cheb basin. The Holocene activity of the MLF, even with surface rupturing, was documented by displaced sediments along the NW part of the MLF (Štěpančíková et al., 2019). The activity of this part of the MLF has continued until today and it overlaps with the West Bohemia/Vogtland earthquake swarm region (Fischer et al., 2014; Štěpančíková et al., 2019). Earthquakes have been registered since the Middle Ages, the strongest one in the instrumental era gives an upper magnitude estimate of the West Bohemia/Vogtland swarms of $\mathrm{M}_{\mathrm{L}}$ 5.0, which corresponds approximately to Mw 4.3 (Jakoubková et al., 2017). In addition, numerous mineral springs and mantle-derived carbon-dioxide emanation was documented from the surrounding of this part of the MLF (Weinlich et al., 1999; Bräuer et al., 2005; Fischer et al., 2017). The NW part of the MLF is probably the most and best studied area of recent tectonic activity in the Bohemian Massif.

The morphological evidence of the MLF in the terrain can be traced for as long as $120 \mathrm{~km}$. A well-expressed escarpment, which is from 50 to $400 \mathrm{~m}$ high, is visible along almost the entire fault (Fischer et al., 2012). The highest fault scarp can be found in the central part of the fault, near Lázně Kynžvart. The fault became less morphologically distinct towards both ends, the north-western near Plauen (in Germany) and the south-eastern near Horšovský Týn. However, the character of the fault escarpment varies in different parts of the MLF, it is possible to observe different grades of tectonic facets evolution, water stream erosion etc. This can indicate a complicated tectonic history and possibly the difference in age and rate of the tectonic movements in the particular segments of the MLF (Badura et al., 2007; Śvancara et al., 2008). The MLF separates two distinct types of relief (Fischer et al., 2012): higher terrain on the eastern side and lower on the western. The crossing of the MLF with the Eger Rift is the only part of the fault where the relatively flat terrain is present on both sides of the MLF. The lower relief is represented by the flat terrain of the Cheb basin, or by 


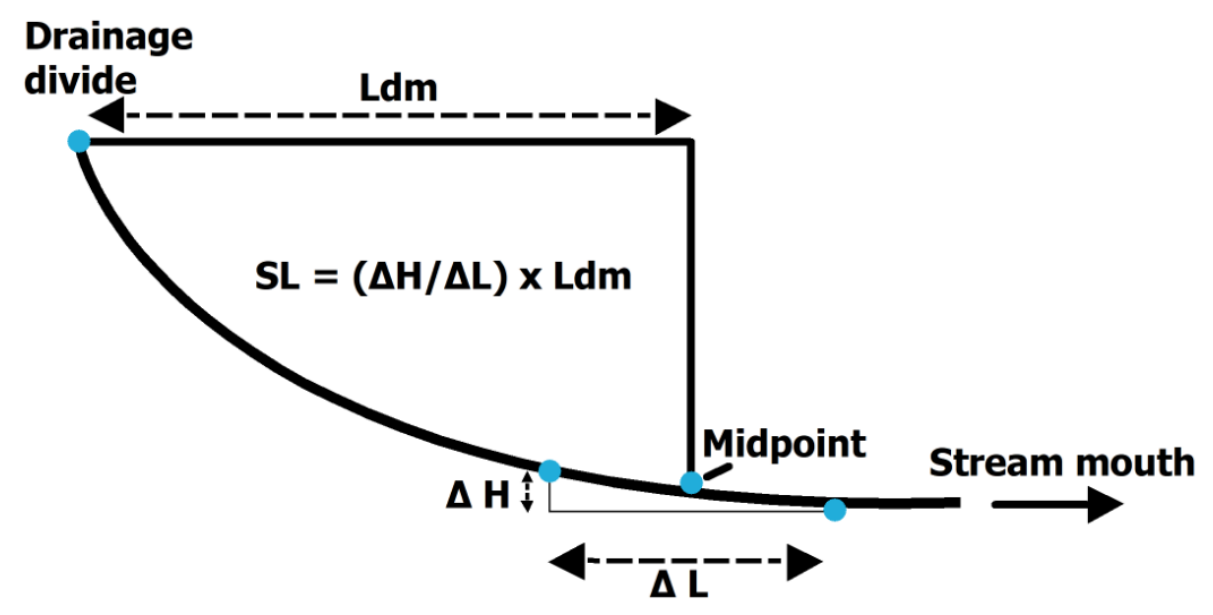

Fig. 3 Calculation of SL index (according to Hack (1973)).

the gently hilly relief of the Cheb - Domažlice Graben. The uplifted eastern part is represented by the Krušné hory Mountains in the NW part of the fault, the very rugged terrain of the Slavkovský les highland in the central part and the rather gentle terrain of the Plaská hilly land (Balatka and Kalvoda, 2006; Bína and Demek, 2012).

\section{DATA AND METHODS}

\subsection{DATA}

Several types of primary data were used during this study. The basic topographic information for calculating morphometric indices was obtained from the digital elevation model (DEM), which was based on aerial laser surveying and measurement: LiDAR resolution $<1$ m (ČUZK, 2017). The information about the lithology and tectonic structure was obtained from basic geological maps of the area (Zoubek, 1963; Vejnar et al., 1978; Vejnar et al., 1978b; Vejnar et al., 1980; Mahel et al., 1984; Müller et al., 1998; Seifert et al., 1998, Adamová et al., 2001), and were locally specified by field survey. Historical sources were used for correcting some faults in topographic maps or for avoiding the anthropogenic influence on water streams. The historical maps (JEPU and ME, 2014) and historical aerial photographs (MGHO, 2014) were used for those adjustments.

\subsection{MOUNTAIN-FRONT SINUOSITY (SMF)}

The mountain front sinuosity index (Smf) (Bull and McFadden, 1977; Burbank and Anderson, 2001; Bull, 2006) is a tool for evaluating the maturity of the tectonic activity and uplift along the fault. The main idea is to compare the length of the mountain foot $(L m f)$ with the straight line $(L s)$.

$$
S m f=L m f / L s
$$

When the uplift is a recent occurrence, the mountain front is straighter (= the index is lower). When the tectonic movements are inactive for a longer time, the fluvial erosion produces the sinuous mountain front (= the index is higher). However, other factors like rock resistance should be evaluated as they can influenced the values of the $\operatorname{Smf}$ (Gutierrez, 2013). The MLF was divided to 17 segments, based on the orientation of the fault and natural breaks in the fault slope (valleys of longer, east-flowing streams). The measurement of the Smf also helped divide the MLF into the particular segments based on the $\operatorname{Smf}$ values. These segments can be further compared to each other regarding $\operatorname{Smf}$, but also regarding the results of the other methods used.

\subsection{STREAM-LENGTH (SL) INDEX}

The SL index (Hack, 1973) can be calculated by the equation

$$
S L=(\Delta H / \Delta L) L d m,
$$

where $(\Delta H / \Delta L)$ is the stream gradient and $L d m$ is the length of the stream reach between the stream source and the middle of the measured part (see Fig. 3).

The values of the SL index react very sensitively to gradient changes of the stream, including lithological, tectonic, hydrological and even anthropogenic influences. However, the sensitivity of the SL index can also be a disadvantage - peaks of the SL index curve are very sharp and local maxima can follow local minima very suddenly. It is useful to use some statistical methods to obtain robust results - such as moving the average when evaluating the SL longitudinal curves, as was done here.

To successfully obtain the SL index values from the selected streams, it is important to select the right source of elevation data. The digital elevation model (DEM) based on LiDAR data was used in this study. The resolution of the DEM was $1 \mathrm{~m}$, which is optimal for such a study, because it provides enough detail, especially regarding the stream geometry.

The longer, east-flowing streams (Kosový, Hamerský, Mže, Výrovský, Úhlavka, Radbuza, see 
Fig. 2) were distributed to $100 \mathrm{~m}$ long reaches, where the SL index was calculated. The shorter, streams were distributed to $10 \mathrm{~m}$ reaches in order to detect any of the small particular changes in the SL index at a smaller scale. However, the raw data was rather unsuitable for the subsequent analyses. It was necessary to modify some values in those places, which were influenced by anthropogenic activities (millraces, dams, weirs etc.). The historical maps and historical aerial photographs (see section 3.1.) were used for those adjustments.

The SL index values were represented by longitudinal curves along the stream profiles and were smoothed by the moving average method (10 values).

The streams situated to the $\mathrm{N}$ from the Ohre River were surveyed by previous studies of Štěpančíková et al. (2019), where the SL index values were obtained and the results were considered in this study.

\subsection{BASIN ASYMMETRY (AF)}

Basin Asymmetry is used to detect tilting in a particular basin due to tectonic movements (Badura et al., 2007; Gutierrez, 2013):

$$
A f=100(A r / A t)
$$

$A r$ is the area of the basin of the right side of the main stream, $A t$ is the total area of the basin. A value of 50 indicates stability, whereas deviations from 50 suggest tilting. Moreover, the asymmetry suggests the direction of tilting, however the effect of lithology (strata dip) should be evaluated (Gutierrez, 2013). The asymmetry in the study area was surveyed in the drainage basins of the smaller, west-flowing streams running down the fault slope. In all, 243 basins were tested in order to find a possible regional trend of titling along the MLF.

\subsection{LONGITUDINAL PROFILES}

Longitudinal profile analysis is a traditional method for detecting a tectonic effect on a water stream (Wheeler, 1979; Burbank and Anderson, 2001). The typical longitudinal profile of a mature, stable water stream (a so called graded river) has a smooth concave shape. Any divergence of this shape is an indication of unstable conditions, however there are many factors which could influence the shape: erosion base level, geological setting, hydrological setting, climate, tectonics (Burbank and Anderson, 2001; Keller and Pinter, 2002; Willet, 2006; Sougnez and Vanacker, 2011). Therefore, it is very difficult to find out the ruling factor affecting a particular water stream. However, the longitudinal profiles can be compared between each other and it could be a strong lead for evaluating the evolution of water steams or a particular catchment.

In this study, two groups of water streams were investigated separately: longer, east-flowing streams, which head towards the fault scarp where they cut it by antecedent valleys (Kosový, Hamerský, Mže, Výrovský, Úhlavka, Radbuza); and shorter streams (243 streams) up to $10 \mathrm{~km}$ long, flowing down the fault slope, generally from $\mathrm{E}$ to $\mathrm{W}$. The analyses of the longer streams were used to evaluate catchment and terrain evolution at the regional scale, the analyses of the shorter streams helped to delineate different segments of the MLF, in combination with other methods such as mountain-front sinuosity and basin asymmetry. The Ohre River is one of the main streams crossing the fault from $\mathrm{W}$ to $\mathrm{E}$, flowing through the Cheb basin. Its evolution and tectonic control have been studied by e.g. Čtyroký (1996) and Balatka et al. (2019). As it is also influenced by tectonic processes in the Cheb basin and Eger Graben, it is not comparable with the other streams mentioned and has not been used in this study.

\section{RESULTS}

\subsection{MOUNTAIN-FRONT SINUOSITY}

Mountain-front sinuosity varies significantly along the MLF (see Fig. 5). The range of values is between 1.06 to 1.63 (see Table 1). The highest values were recorded in the small, relatively isolated segments, however, an interesting series of neighbouring segments with relatively high values can be found in the area of Slavkovský les (segments no. 4-8). The lowest values (1.06) were found in the NW part of the MLF (segment no. 1). The low values are located $(1.2-1.23)$ in the central part of the MLF (segments no. 11-14). Those results might not be so surprising, as the most recent tectonic activity is expected to be primarily in those parts of the MLF.

Table 1 Values of the mountain-front sinuosity (Smf). $\mathrm{Lmf}=$ length of mountain front, Ls = length of straight line.

\begin{tabular}{lrcc}
\hline $\begin{array}{c}\text { Segment } \\
\text { no. }\end{array}$ & Lmf (m) & $\begin{array}{c}\text { Ls } \\
(\mathbf{m})\end{array}$ & Smf \\
\hline 1 & 2664 & 2515 & $\mathbf{1 . 0 6}$ \\
2 & 3375 & 2574 & $\mathbf{1 . 3 1}$ \\
3 & 4537 & 4080 & $\mathbf{1 . 1 1}$ \\
4 & 3543 & 2754 & $\mathbf{1 . 2 8}$ \\
5 & 8146 & 5951 & $\mathbf{1 . 3 6}$ \\
6 & 8182 & 6059 & $\mathbf{1 . 3 5}$ \\
7 & 4387 & 3450 & $\mathbf{1 . 2 7}$ \\
8 & 5462 & 4140 & $\mathbf{1 . 3 1}$ \\
9 & 4089 & 2585 & $\mathbf{1 . 5 8}$ \\
10 & 4860 & 3891 & $\mathbf{1 . 2 5}$ \\
11 & 4118 & 2525 & $\mathbf{1 . 6 3}$ \\
12 & 4546 & 3675 & $\mathbf{1 . 2 3}$ \\
13 & 10747 & 8956 & $\mathbf{1 . 2 0}$ \\
14 & 2064 & 1381 & $\mathbf{1 . 4 9}$ \\
15 & 5578 & 4723 & $\mathbf{1 . 1 8}$ \\
16 & 6363 & 4863 & $\mathbf{1 . 3 0}$ \\
17 & 11885 & 9760 & $\mathbf{1 . 2 1}$ \\
18 & 8191 & 5200 & $\mathbf{1 . 5 7}$ \\
\hline
\end{tabular}




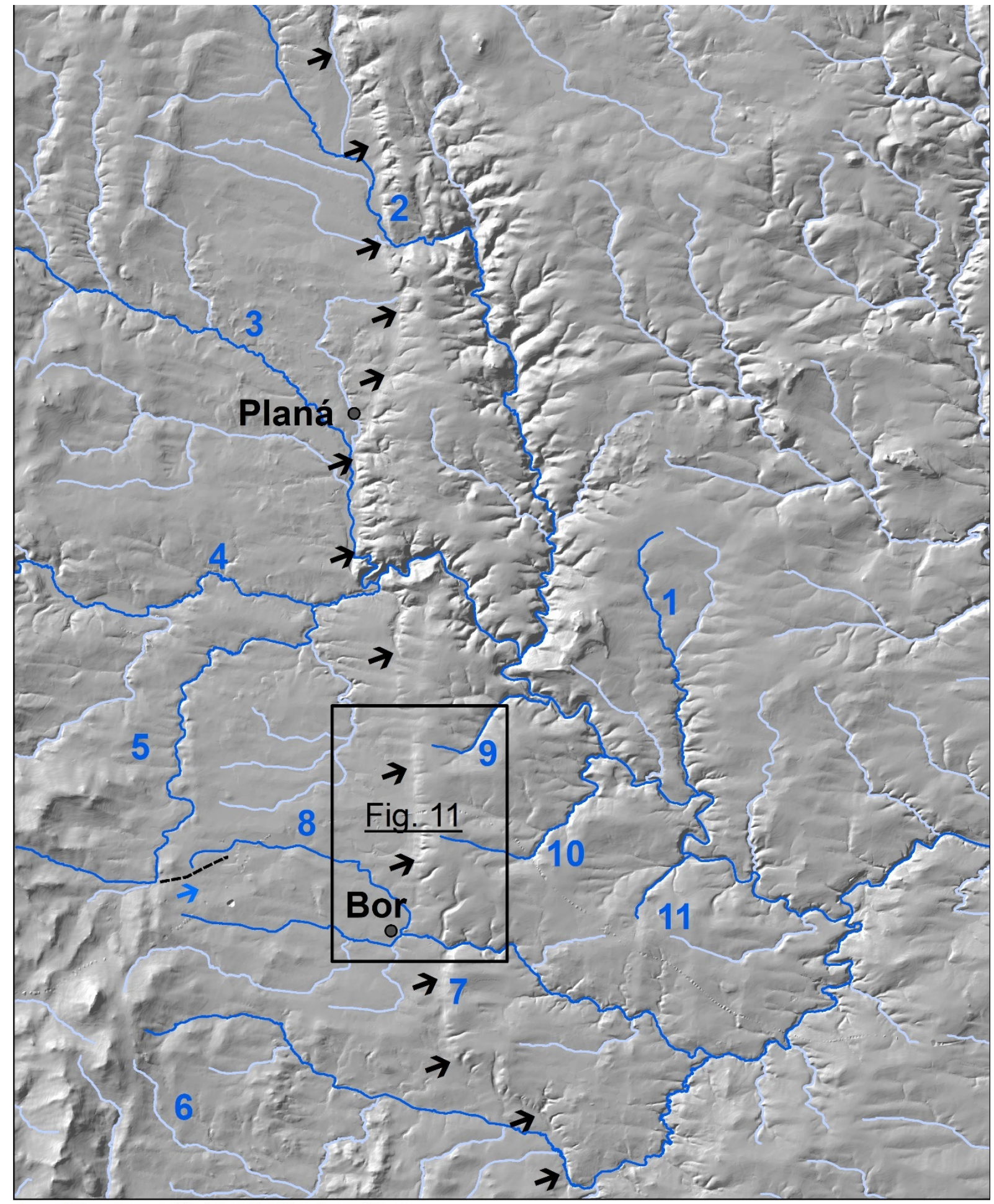

- Streams with longitudinal profiles

Other water streams

---- Possible past course of Sedlišt'ský stream

1 Analysed water stream (see text)

7 MLF course delineation

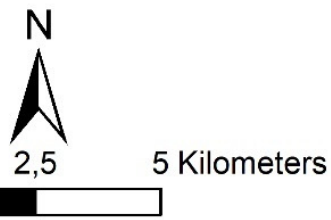

Fig. 4 Detailed map of the central part of the MLF. Area around Bor is enlarged on Figure 11. Names of the streams: 1 - Černošínský, 2 -Kosový, 3 - Hamerský, 4 - Mže, 5 -Sedlištský, 6 - Úhlavka, 7 - Výrovský, 8 - Lukavický, 9 - Veský, 10 - Š́rka, 11 - Lomský. Note the proposed past course of the Sedlišt'ský stream (see section 5.2, Fig. 8 and Fig. 14). 


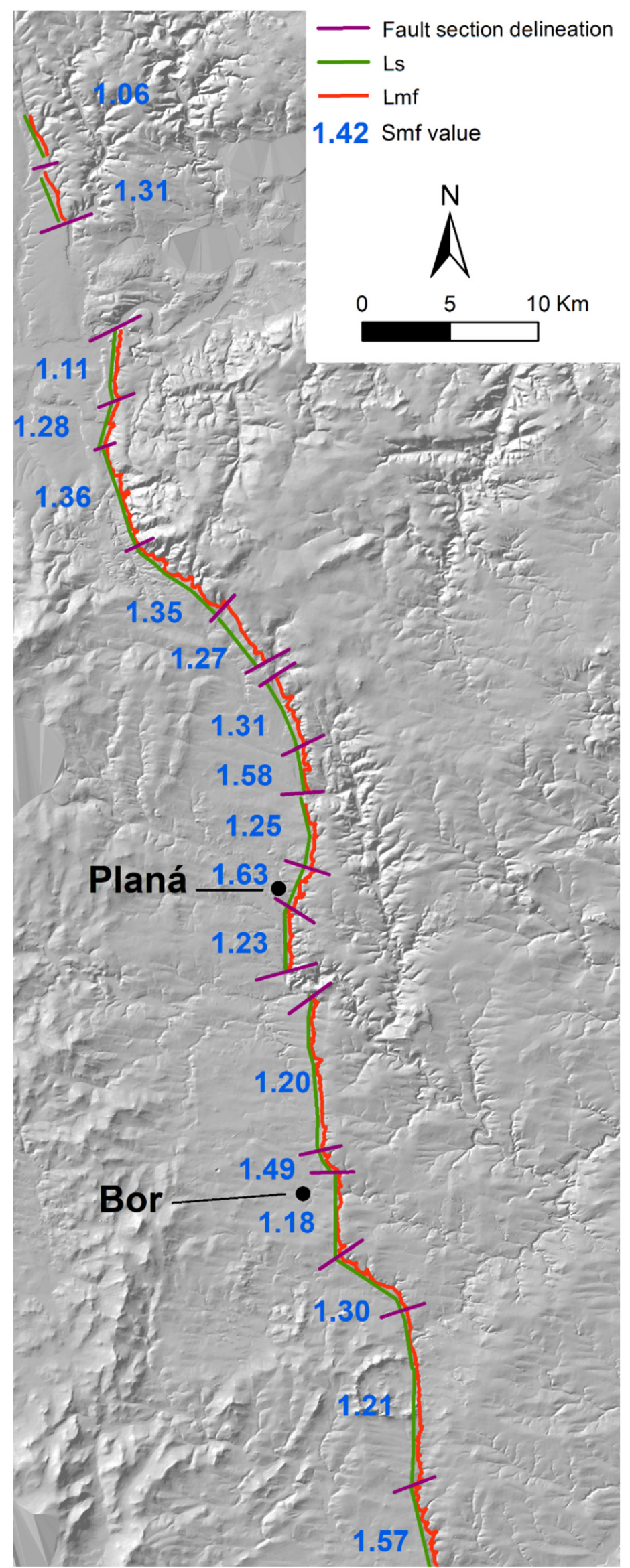

Fig. 5 Mountain front sinuosity and delineation of the segments of the MLF in the study area. $L m f=$ length of the mountain front, $L s=$ length of straight line. For evaluation of the influence of lithology see Figure 1. 


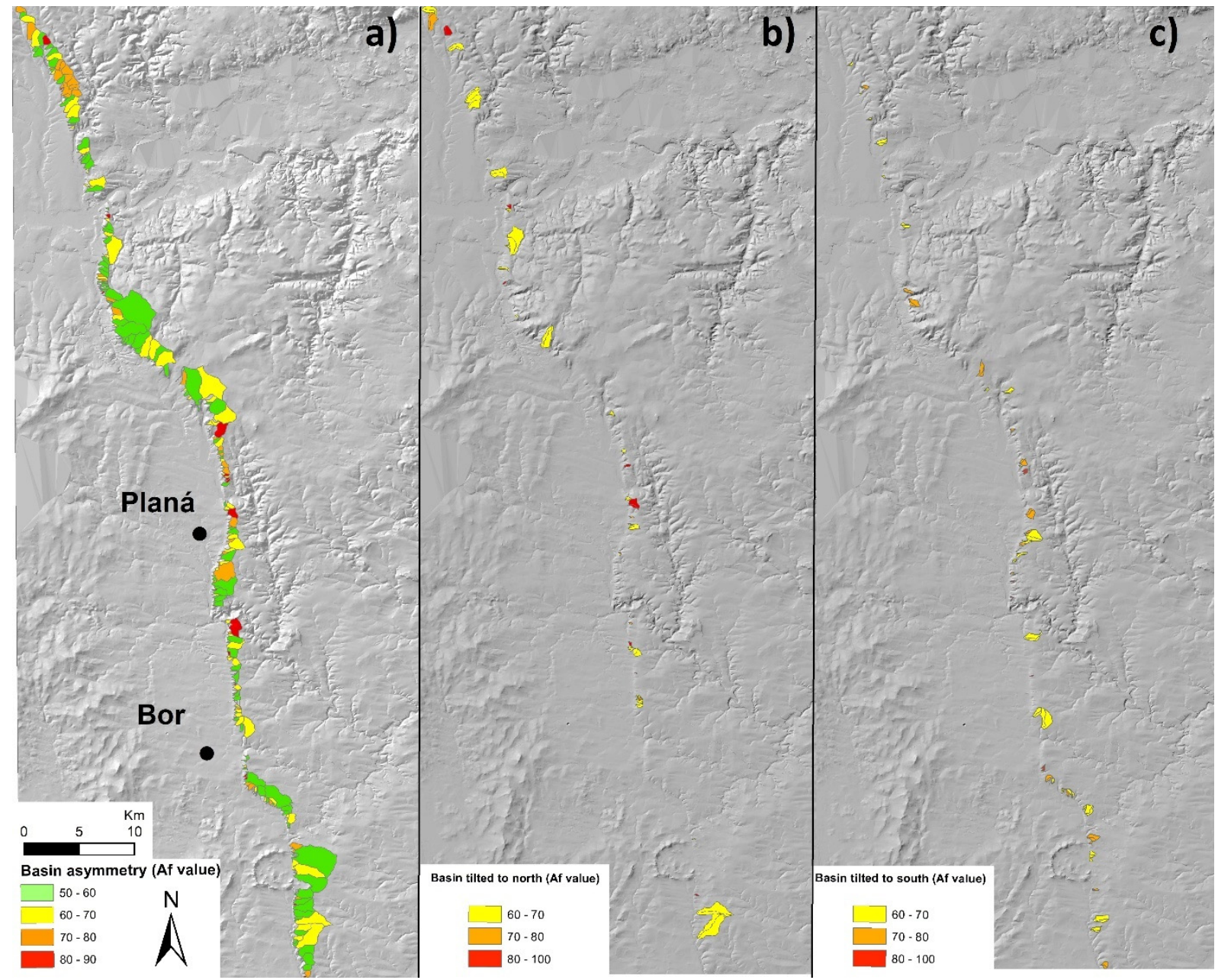

Fig. 6 a) Basin asymmetry values along the MLF, b) Basins tilted to the north, c) Basins tilted to the south.

\subsection{BASIN ASYMMETRY}

The values of basin asymmetry are variable along the MLF (see Fig. 6a). Out of 243, there are 121 basins with higher symmetry $(A f=50-60), 69$ basins with a value $A f$ between 60 and 70 , and 53 basins with an $A f$ between 70 and 100 (see Tab. 2 - supplementary file, attached as "asym.xls"). No obvious spatial trend of basin asymmetry values along the MLF was found. However, some segments containing basins with higher asymmetry could be located. Segments $a$ and $b$ contain 8 basins with an $A f$ higher than 70 . In addition, the segments $e, f$ and $g$ show a higher number of asymmetric basins (out of 90 basins there are $9 \times A f>80,15 \mathrm{x} A f>70,30 \mathrm{x} A f>60$ ). On the other hand, the parts of the MLF which bend towards the W (segments $d$ or $h$ ) seem to have more symmetric basins compared to those mentioned above (see Fig. 2 and Fig. $6 a$ for the position of particular segments).

Another expression of tectonic control in the basins could also be the direction of the basin asymmetry (see Figs. $6 \mathrm{~b}$ and $6 \mathrm{c}$ ). The movement of the trunk stream to the north part of the basin could be a result of the basin tilting to the north and the uplift of its southern part. This could be a trace of regional tilting, which can be found along some segments of the
MLF, however the results are not very strong and the fact that there is no particular spatial trend indicate that the effect of strata dip may well play its role (see section 5.1.). The segment $a$ has signs of tilting to the north. Tilting to the north also could be present in the very southern end of the studied part of the MLF (segment $i$ ) and also in segments $f$ and $g$ in the central part of the MLF (see Fig. 6b). Less distinctive tilting to the south was found in the central and southern part, segment $h$ (see Fig. 2 and Fig. 6c).

\subsection{LONGITUDINAL PROFILES AND STREAM GRADIENT}

\subsubsection{EAST-FLOWING STREAMS}

The longer, older streams flowing towards the MLF-related fault scarp, where they cut it by antecedent valleys, show signs of maturity. However, there are parts on the streams which diverge significantly from the ideal profile, which might be a possible result of tectonic activity.

The steepest section (or knickpoint) on the Mže River is located roughly between 35 and $40 \mathrm{~km}$ from the source: Figure 8 and Figure 10. It lays down the stream from the crossing of the MLF, so a direct effect of the fault could be excluded. The steepening of the 


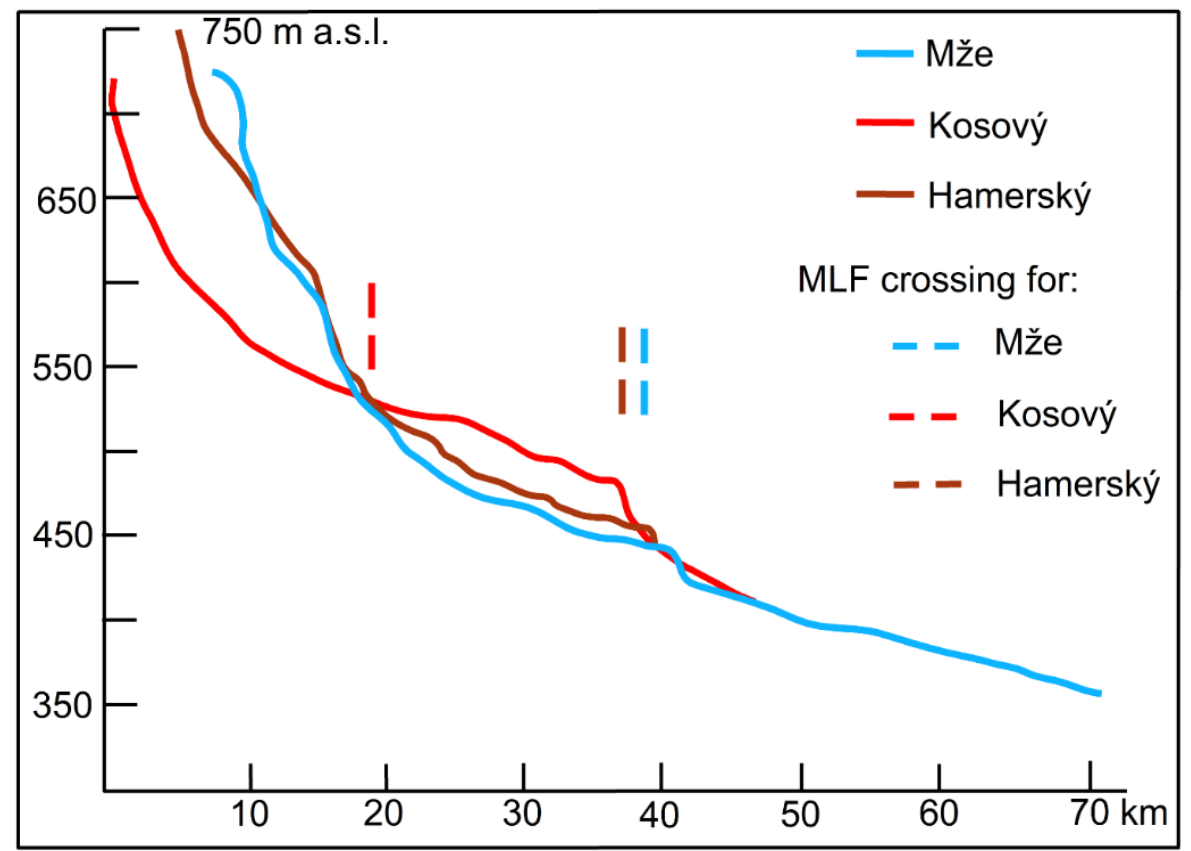

Fig. 7 Comparison of the longitudinal profiles of the Mže River and its tributaries. Horizontal distance is measured form the source of the Kosový stream. Note the crossings with the MLF. For the topographical position of the crossing see Figure 4.

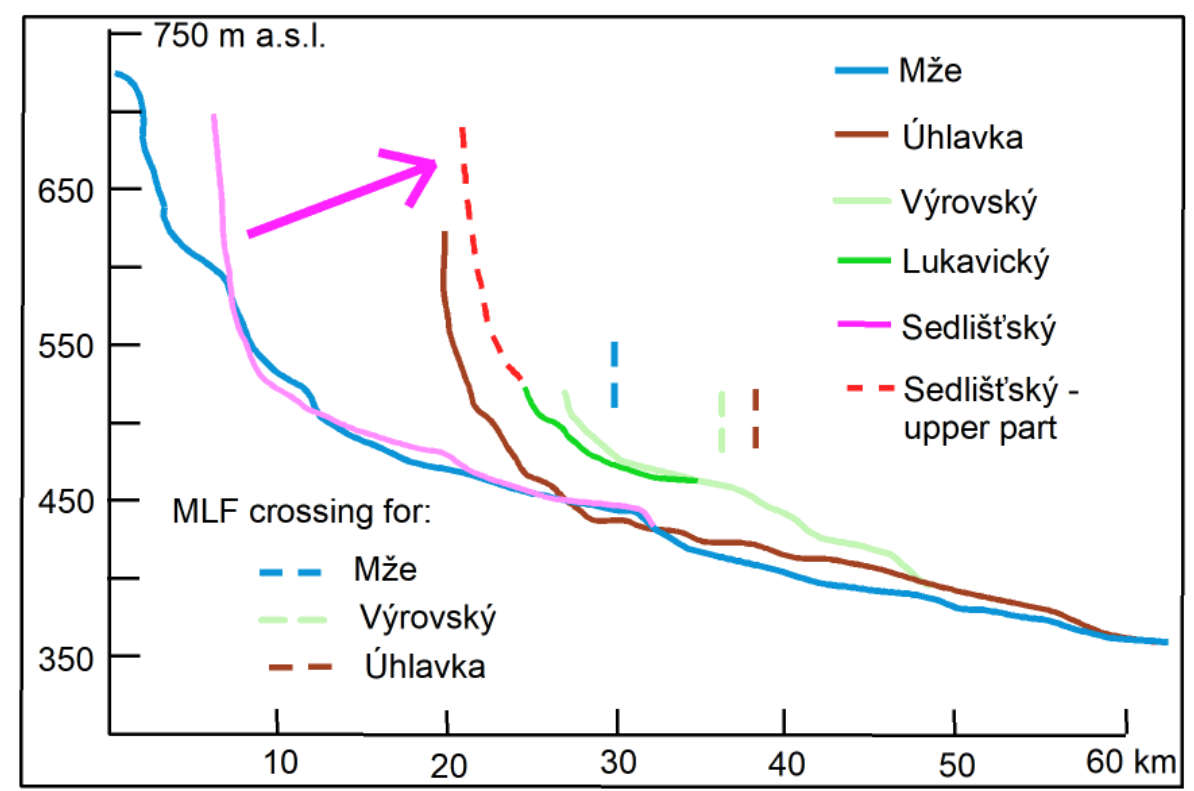

Fig. 8 Comparison of the longitudinal profiles of the Mže River and its tributaries. Note the almost ideal possible former connection between the upper part of the Sedlišt'ský stream and the lower part of the Lukavický stream (see section 5.2., Fig. 4 and Fig. 14). Horizontal distance is measured from the source of the Mže River. Note the crossings with the MLF. For the topographical position of the crossing see Figure 4.

gradient (7-10\%) could be a combination of bedrock resistance, headward erosion and regional uplift.

The Kosový stream has a very interesting course with two rectangular bends, which might indicate a stream capture (Fig. 4). These changes in course orientation can also be partially detected in the changes of the stream gradient. The section between 25 and $30 \mathrm{~km}$ (see Fig. 7) shows a gentle rise in the stream gradient (from $2 \%$ o to $10 \%$ ). This section lays directly down the stream from the rectangular bend where the Kosový stream changes its direction from WSW-ENE to NNW-SSE (see Fig. 4). These gradient changes could be correlated with the processes of stream capturing (Demek and Czudek, 1957). The most interesting knickpoint on the Kosový stream lies between 35 and $39 \mathrm{~km}$. This section has an untypically high stream gradient (locally over $20 \%$ ), incomparable with similar streams in the area. It could 


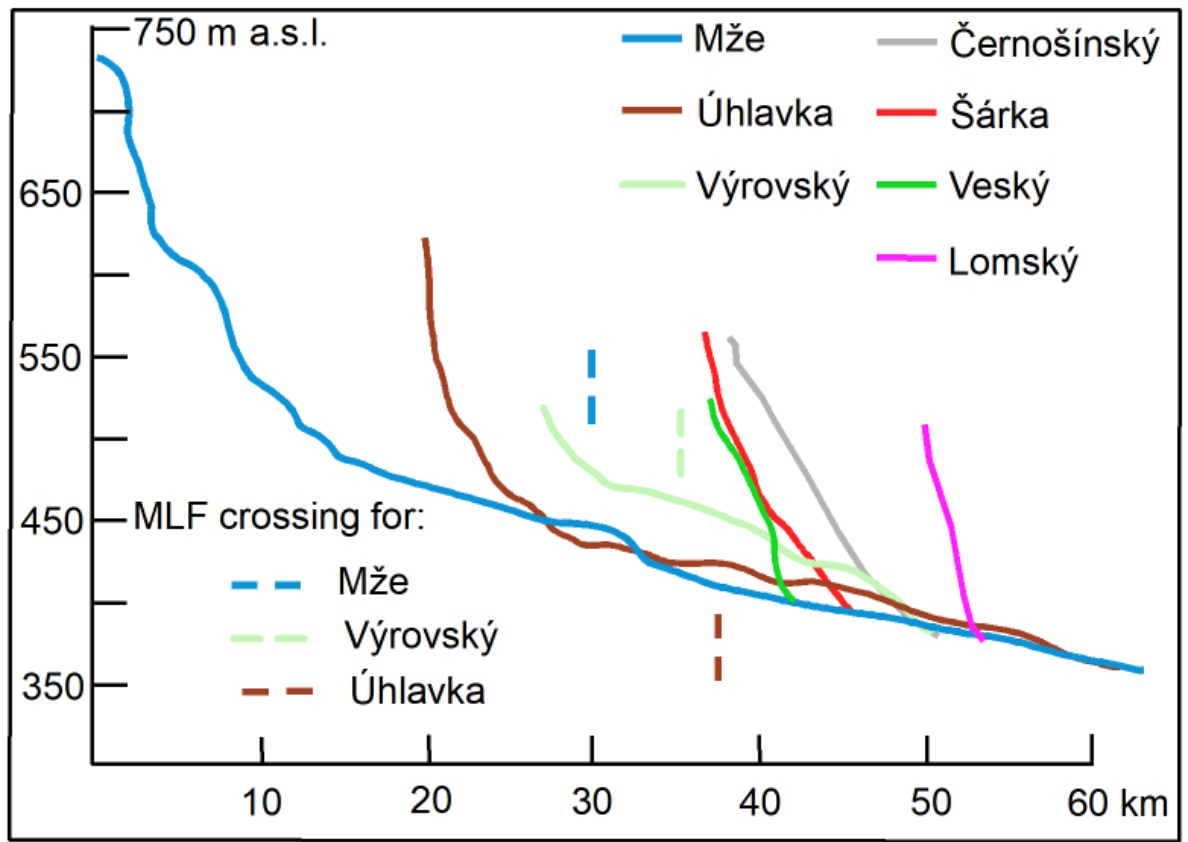

Fig. 9 Comparison of the longitudinal profiles of the Mže River and its tributaries. Horizontal distance is measured from the source of the Mže River. Note the crossings with the MLF. For the topographical position of the crossing see Figure 4.

partially be controlled by bedrock resistance, however, a tectonic effect cannot be ruled out. The neighbouring Mže River also has a similarly steep section (see Fig. 7), however it seems that its origin differs in time and/or cause, because of differences in the steepness, exact localization etc.

The Hamerský stream has quite a mature longitudinal profile, however, with an untypical, steep section near the confluence with the Mže River (Fig. 4, Fig. 7, Fig. 10; over $10 \%$ gradient) which is related to the valley section being deeply incised through the fault slope. The origin of these features is probably caused by headward erosion from the incising main stream of the Mže River.

The Úhlavka River is a right-sided tributary of the Mže River. Its longitudinal profile is more mature, compared to other streams in the area (see Fig. 8 and Fig. 9). However, its tributary, the Výrovský stream, has a stepped profile with several knickpoints (locally a 25-30\%o gradient).

The lower part of the Výrovský stream (respectively its tributary the Lukavecký stream) is almost an ideal continuation of the upper parts of the Úhlavka River and the Sedlišt'ský stream considering the shape of the longitudinal profile. This relation between longitudinal profiles as well as geographical relations, suggests that stream capturing here was very probable (see section 5.2., Fig. 4, Fig. 8 and Fig. 14).

The tributaries of the Mže River, which are located between the Kosový stream and the Úhlavka River (Š́rka, Veský, Lomský and Černošínský streams - see Figs. 4 and 9), have very steep longitudinal profiles (3-10\% along the majority of their length). They are very similar to each other, however they are quite different from the other streams mentioned above, which have more mature, hyperbolic profiles. None of them cross the MLF, their profiles seem to be undisturbed by distinctive knickpoints and their steep profile should be a results of intensive incision of the trunk stream, the Mže.

The longitudinal profile of the Radbuza River has a similar shape as that of the Mže River (see Fig. 10). There are several smaller knickpoints (21 km and $45 \mathrm{~km}-10$ and $8 \%$ ) along the course, but they can be more likely interpreted as a result of changes in the lithological composition. The most interesting part is the low gradient ( $\max 3 \%$ ) section between 3 and $8 \mathrm{~km}$. The sharp change to a higher gradient part down the stream (over $10 \%$ ) is linked with the stream's sudden change of direction in from S-N to W-E. Past stream capturing is very probable here.

\subsubsection{WEST-FLOWING STREAMS}

The longitudinal profiles of the W-flowing streams show great variability. However, there are streams with similar profiles near to each other, so the study area can be classified into several clusters or segments. Concave longitudinal profiles (graded profiles) can be found in the area of Slavkovský les and also between the Výrovský and Úhlavka streams (Fig. 4). This probably means a longer period of erosion activity (compared with the relatively low basin asymmetry within those parts of the MLF Fig. 6). On the other hand, a higher number of convex profiles can be found in particular areas: in the SE near Horšovský Týn, in the NW between Kynšperk n/O and 

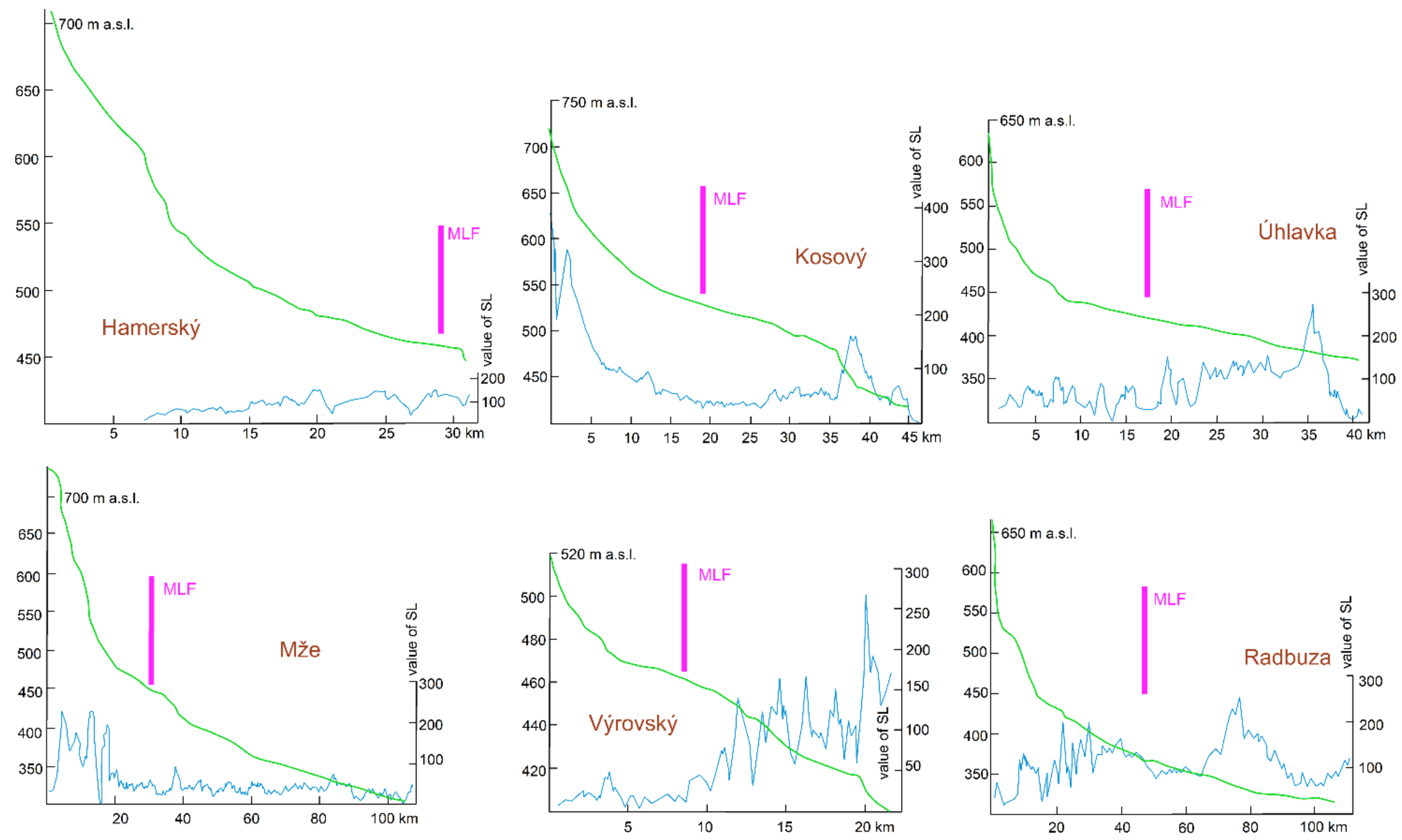

Fig. 10 Longitudinal profiles of the east flowing streams + SL index curves. 


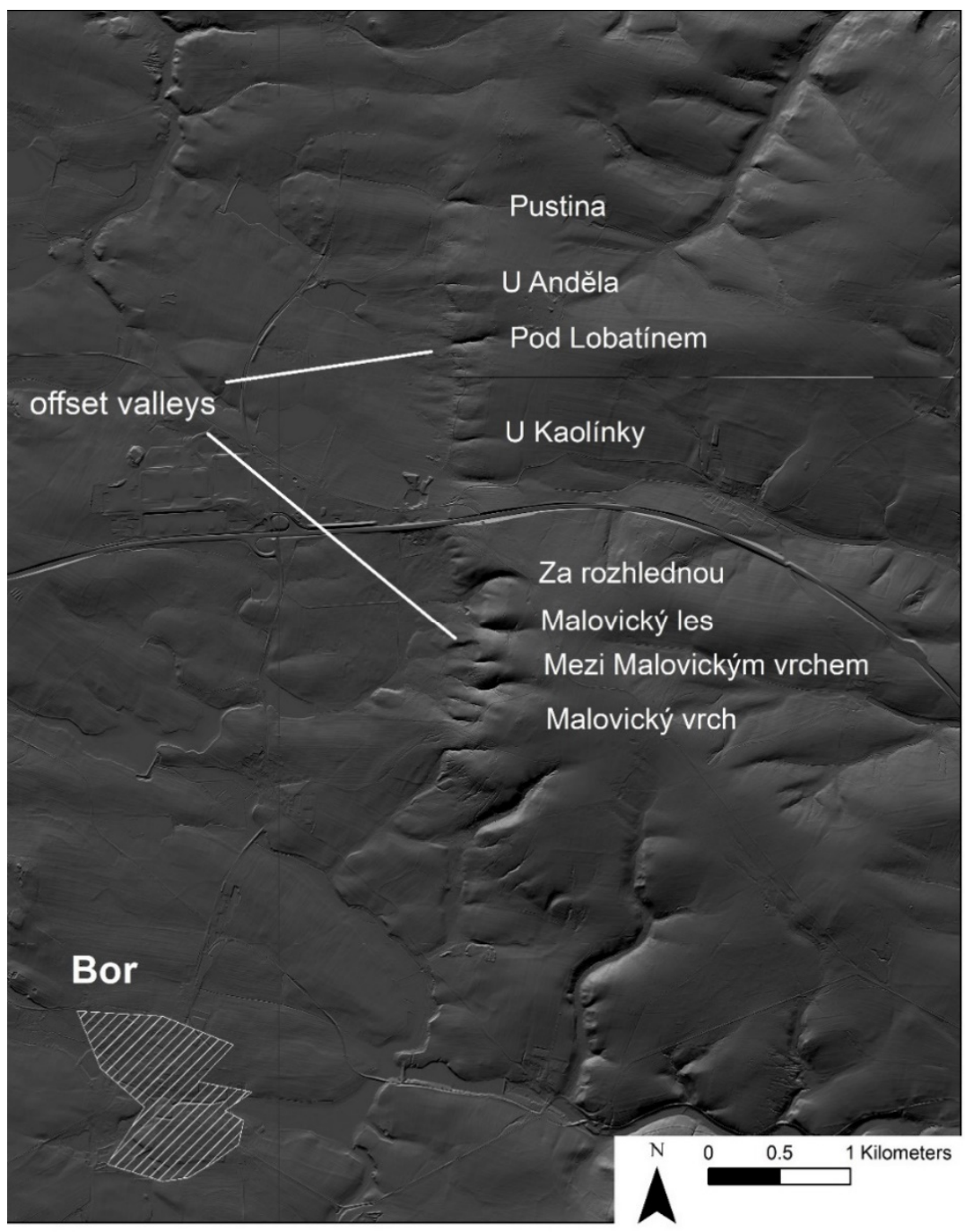

Fig. 11 Segment of the MLF to the north from the town of Bor with west-flowing streams with highly convex longitudinal profiles (see Fig. 13). Note also the significant course of the fault slope foot and the offset valleys (particularly "Mezi Malovickým vrchem", "Pod Lobatínem" and "Pustina").

the Czech-German border, and, especially, in the central part between Planá and Bor (where the values of basin asymmetry are relatively higher - Fig. 6). The central part of the MLF was investigated in detail, as the most promising area for subsequent field research of recent tectonic activity. There are 20 west-flowing streams in segments $f$ and $g$ of the MLF (Fig. 2, Fig. 12). In particular, the area $5 \mathrm{~km} \mathrm{~N}$ from Bor (see Fig. 11) shows 8 streams (Pustina, U Anděla, Pod Lobatínem, U Kaolínky, Za Rozhlednou, Malovický les, Malovický vrch, Mezi Malovickým vrchem) with particularly convex profiles (see underlined stream names in Figure 12). It is also possible to find the morphologically very prominent course of the MLF fault slope foot and the stream valleys, which are significantly offset, in this part of the MLF (see Fig. 11). This situation is very similar to the NW part of the MLF (Štěpančíková et al., 2019). Therefore, young tectonic activity with both vertical and horizonal component of movements can also be expected and it should be a subject for further research.

\subsection{SL INDEX \\ 4.4.1. EAST-FLOWING STREAMS}

The values of the SL indices were smoothed by the moving average tool to obtain a better view of the regional trends of values. No strong anomalies of SL index values were measured near the crossings of the streams and the MLF. Instead, a rise of SL index values (up to 300) was measured in the whole area that lays down the stream from the MLF crossing. Still, differences between particular streams can be observed, which could be caused by different lithology, an uneven rate or age of the uplift or other effects (see section 3). The Mže River (see Fig. 10) has two main increases (220 and 100) in the SL index value: around $15 \mathrm{~km}$ and $40 \mathrm{~km}$. The first one is linked 

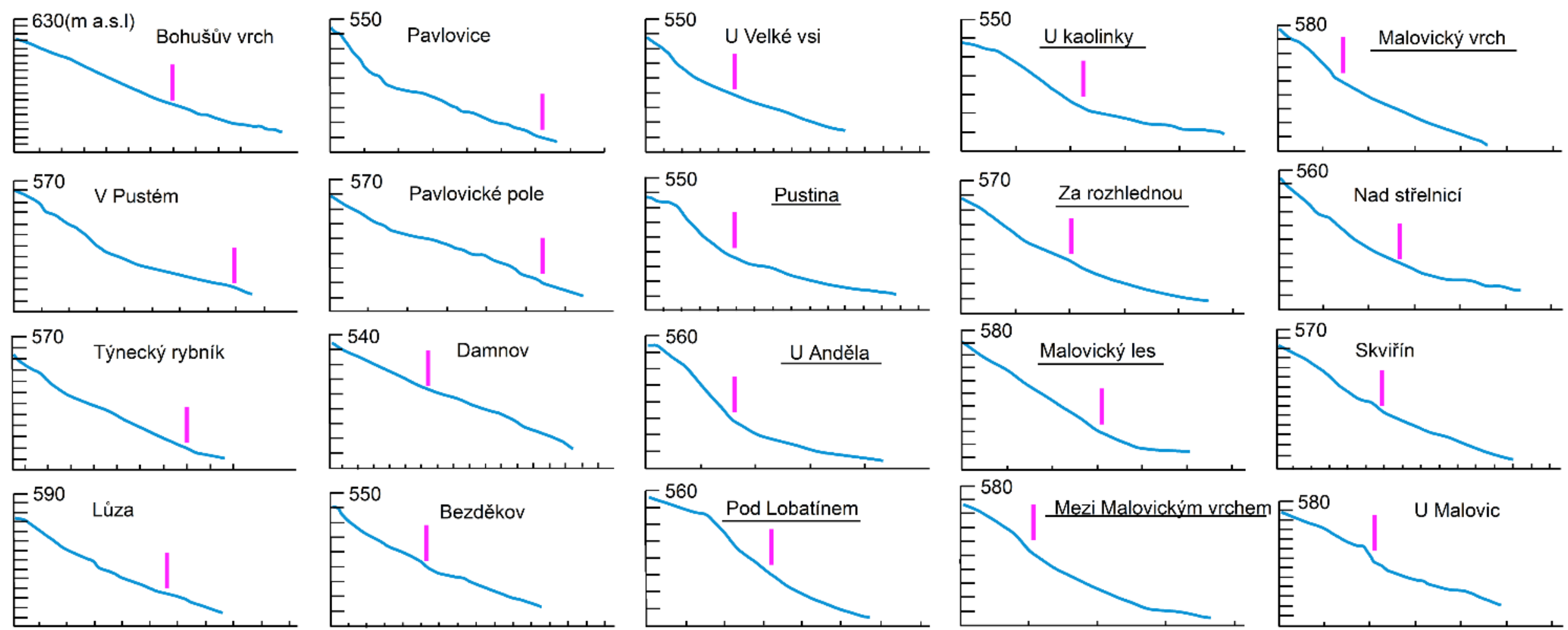

vertical scale: one division $=10 \mathrm{~m}$, horizontal scale: one division $=200 \mathrm{~m}, \quad$ = MLF crossing

Fig. 12 Longitudinal profiles of the streams between Planá and Bor. Note the significant convex profiles - with underlined stream names (for detailed profiles see Figure 13, for the morphological situation see Figure 11). 

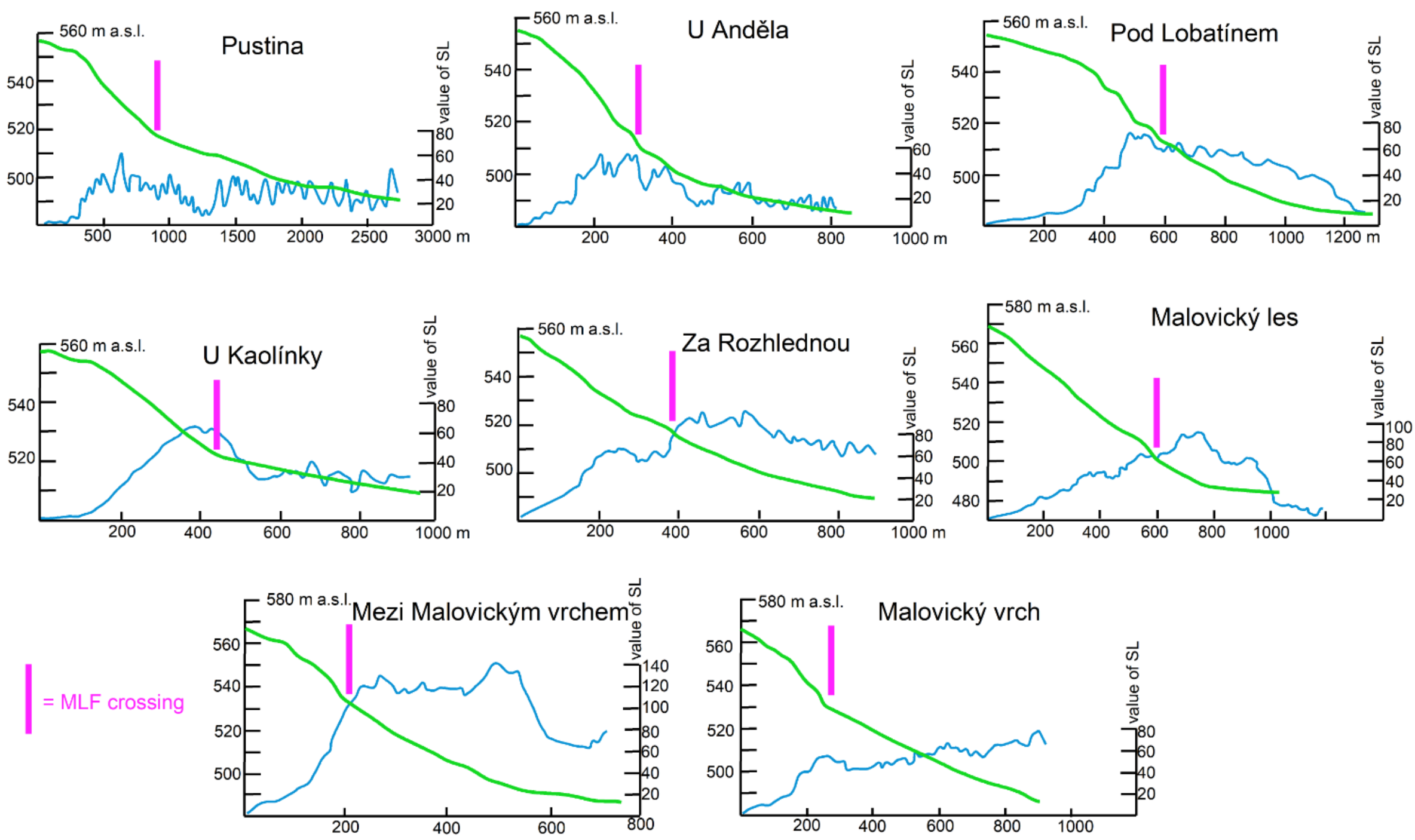

Fig. 13 Longitudinal profiles and SL value curves of the selected west-flowing streams in the central part of the MLF (see Fig. 11, Fig. 12). 
to the knickpoint following the flat section on the upper part of the stream. A more important peak in high SL index values lies at $40 \mathrm{~km}(5 \mathrm{~km}$ down the stream from the MLF crossing). The Kosový stream has the most interesting changes in its SL values on its lower course: a gentle rise in SL index values between $26 \mathrm{~km}$ and $35 \mathrm{~km}(\mathrm{SL}=50)$ and, in particular, a very prominent peak of values between $36 \mathrm{~km}$ and $39 \mathrm{~km}$ $(\mathrm{SL}=180)$. Compared to the Mže River and Kosový stream, the Hamerský stream does not have any prominent peaks in its SL index values. There is only a gentle rise of values $(\mathrm{SL}=100)$ by the crossing of the fault. The Výrovský stream is remarkable due to its two knickpoints (12-15 km and 20-22 km, SL= 160 and 260) down the stream from the MLF. The SL index values on the Úhlavka River show a gradual rise downstream from the MLF crossing ( $\mathrm{SL}=40-130$ ), but the main peak is located near its mouth to the Mže River ( $S L=280$; see Fig. 10). The Radbuza River has different SL index values along its course, compared to other streams in the area. A rise in the values is located several kilometres down the stream from the crossing; the values are untypically low here $(\mathrm{SL}=$ 100). A remarkable rise in the SL index values is located around $80 \mathrm{~km}(\mathrm{SL}=250)$.

\subsubsection{WEST-FLOWING STREAMS}

The SL indices measured on the consequent $\mathrm{W}$ flowing streams span from 0 to 1000 . Due to the difficulty of comparing the SL indices between the streams, sudden changes in values on particular streams were investigated rather than comparing the absolute values. The high values and sudden changes in SL index are located on the slopes of Slavkovský les, in segment $d$ of the MLF. The high SL index values are linked with the high stream gradient in the area, where the upper parts of the streams are flat and then very steep in the middle part. Segment $i$ is the other area that has sudden changes in SL index values. Remarkable results were obtained by Štěpančíková et al. (2019) in segment $a$, where several fault segments were marked as active based on the SL-index values. Despite the distinctive fault scarp morphology and suspected valley offsets in segment $g$ of the MLF (Fig. 2 and enlarged in Figure 11), no high SL index values were obtained from this central part of the MLF. This might be caused by the lower relief and lower water discharge in the area, so the valleys are young and undeveloped. The streams Pod Lobatínem, U Kaolínky, Za Rozhlednou a Malovický les showed very similar longitudinal curves (Fig. 13). The peaks of SL index values correlated with the foot of the fault slope, and therefore young MLF activity is probable.

\section{DISCUSSION}

\subsection{SEGMENTATION OF THE MLF AND EVALUATION OF THE METHODS USED}

The delineation of the MLF to the particular segments was based on the values of mountain front sinuosity and its strike. Nevertheless, the results of the other methods used- mainly the basin asymmetry and partially the longitudinal profiles analyses - led to a very similar delineation. The results of these different methods suggest that the tectonic activity occurred at different times and/or with variable intensity along the MLF. The NW part - segments $a$ and $b$ - (orientation NNW-SSE), the central part segments $f$ and $g$ - (orientation N-S), and the southern part - segment $i$ - (orientation NNW-SSE) are the segments, where the activity probably occurred most recently. On the other hand, the bended segments $-d$ or $h$ - (orientation NW-SE to NNW-SSE), are probably the ones which experienced uplift for a longer time.

The methods used in this study were also applied in several studies from different parts of the Bohemian Massif (Badura et al., 2007; Štěpančíková et al., 2008). The lithological and tectonic setting there is similar to the study area along the MLF. Particularly, the study by Badura et al. (2007) of the Sudetic Marginal Fault showed very similar results. The methods of mountain front sinuosity and basin asymmetry could provide quite valuable results for assessing tectonic activity at the regional scale, especially where possible lithological control can be ruled out. For example, the mountain front sinuosity values can be strongly affected by the bedrock's resistance to erosion (softer rocks, e.g. sediments, can show higher values of sinuosity), nevertheless, the lowest values of mountain front sinuosity can be found in the softer rocks (phyllites, shales) along the MLF. So, it is assumed that the effect of tectonics overrules the effects of lithology in this case. The other issue is the orientation of the rock structures (e.g. strata dip) which could influence the geomorphological indices as well. In particular, the values of basin asymmetry and the direction of basin tilt could be strongly affected. The dip of the phyllites and schists (CGS, 2003) in segments $a$ and $b$ is $\mathrm{N}$ or NNW, which is in concordance with the proposed tilt of basins in this area. Therefore, it can be expected there is a strong lithological influence here, but it is possible to find basins with a similar tilt in segment $c$, where a granite basement without any specified dip is located. However, the basin tilt direction cannot be used as a strong proof of tectonic evolution along the MLF because of the aforementioned reasons.

The results of the longitudinal profile analyses of the shorter west-flowing streams are concordant to the results of mountain front sinuosity and basin asymmetry and they suggest more recent tectonic activity on the same segments (segments $a$ and $b$, segment $g$; see sections 4.1., 4.2., 4.3. and figures therein). However, the hydrological and lithological conditions might also have controlled the results in some parts, since these conditions vary regionally.

Moreover, the results of SL indices on the westflowing streams show a similar pattern as the results of mountain front sinuosity, basin asymmetry and longitudinal profiles. The highest SL index values can be found in segment $d$ of the MLF (Fig. 2), where the stream gradient and elevation differences are high. However, interesting SL index values - the sudden 
changes indicating young tectonic activity - can be found on the streams in segments $a$ and $b$ (for details see Štěpančíková et al., 2019) or segment $i$ and particularly in the central part of the fault (segments $f$ and g): "Pod Lobatínem", "U Kaolínky", "Za Rozhlednou" and "Malovický les streams". Those streams also have significantly offset valleys, which suggest horizontal movement along the MLF, which is in concordance with the kinematics proposed by Špičáková et al. (2000). In addition, the morphology of the very recent fault scarp, similar to segments $a$ and $b$ (where the neotectonic activity was proved by paleoseismic survey by Štěpančíková et al. (2019) in this area supports the hypothesis of quite young tectonic activity in this segment of the MLF.

In contrast, the of SL index values measured on the longer, east-flowing streams are not significant for any MLF segmentation. The peaks in the SL index, which would suggest the effect of vertical tectonic movements, can be found on some of them. The higher values of gradient and, therefore, also the SL index on the Mže River (around $15 \mathrm{~km}$ from the source) could be caused by the general uplift of the Český les mountains. The most significant peaks in the SL index values are, however, located downstream from the MLF crossing - Mže (40 km), Hamerský (30 km), Výrovský, Kosový, Úhlavka, Radbuza. Those can be interpreted as a result of uplifting of the whole block to the west from the MLF and therefore induced backwards incision, or - in the case of the Výrovský stream (peak at 12-15 km) - as a result of lithological change (granites vs. metapelites). The peak of values on the Radbuza River $(80 \mathrm{~km})$, which differs from the other streams, may be caused by lithological change or by the different uplift rate of a separated tectonic block. The remarkable peaks in SL index values on the lowest parts of the Kosový (36-39 km), Úhlavka $(36 \mathrm{~km})$ and Výrovský $(20-22 \mathrm{~km})$ streams can be explained as the result of an incision of the trunk stream (the Mže River), which led to the formation of knickpoints on tributaries, and was probably caused by the final (Plio-Pleistocene?) phase of the regional uplift (Fig. 10), suggested by relief character and sedimentation in the Cheb-Domažlice Graben. This situation further supports the hypothesis about the evolution of the local stream network (see section 5.2.).

The division into particular segments based on varying fault strike and geology is distinct and in strong correlation with the results of the morphometric methods applied, so it supports the hypothesis of variable tectonic activity along the MLF. It is proposed that segments $a, b, c, f, g$ and $i$ were the more active ones in recent history (Pleistocene - Holocene?). Unfortunately, only segments $a$ and $b$ have been previously studied by palaeoseismology or detailed geophysics so far (Procházková et al., 1998; Švancara et al., 2008; Fischer et al., 2012; Halpaap et al., 2017; Blecha et al., 2018; Štěpančíková et al., 2019). These studies agree on that the youngest tectonic activity occurred in this NW part of the MLF. Švancara et al. (2008) calculated the relative reactivation potential for faults in the area of western Bohemia. He suggested that the particular segments of the MLF with orientation from NNW-SSE to N-S are oriented favourably to reactivation, which are exactly the segments mentioned above. So recent tectonic activity along these segments is very probable.

\subsection{EFFECT OF THE UNEVEN UPLIFT ON THE EVOLUTION OF THE STREAM NETWORK}

The evaluation of longitudinal profiles as well the analysis of the SL indices of the streams flowing to the east toward the fault scarp is much more complex due to the varying hydrological situation and the evolution of the streams. The shapes of the profiles could be a hint to the regional terrain and river network evolution, but it is not the definitive final prove of the following proposal for stream network evolution.

Traditionally, anomalies in the longitudinal profiles of the main rivers in the Bohemian Massif were linked to climatically controlled changes of the erosion base-level. However, the profile anomalies in the area of the MLF could also have different causes (i.e., tectonic uplift, lithological changes). If the wave of the headward erosion has moved up the streams simultaneously from the trunk stream to its tributaries, the present location of knickpoints could be comparable (Bishop et al., 2005). However, the location of knickpoints on the trunk stream of the Mže River differ from their location on its tributaries. Therefore, their origin could be linked to tectonic activity. Moreover, the shorter tributaries of the Mže (Černošínský, Šárka, Veský, Lomský) that are not crossing the MLF, do not express any distinctive knickpoints. This suggests that they have been affected by the general uplift of the area of the Plaská pahorkatina hilly land and their steep profiles originated in the incision of the trunk stream - the Mže River (Fig. 9). Therefore, it is assumed that the different locations of the knickpoints along the streams (Kosový, Hamerský, Úhlavka, Výrovský, Mže) are caused by uneven uplift along the MLF, which might possibly have occurred in a few chronologically separated events. The tectonic activity of particular segments of the MLF - and thus the incision of streams - could have varied in time. In that case, incision through the fault slope by the particular streams and capturing the catchment to the west from the MLF could also have happened at different times. The traces of such a process can be seen in the present shape of the stream network (direction changes, stream capturing). A hypothesis of the subsequent evolution of the present-day morphology is presented here (see Fig. 14):

Stage a) might have taken place in the Pliocene: The Cheb-Domažlice Graben was an area of fluvial and fluviolacustrine sedimentation (dated by Teodoridis et al. (2017)). The MLF scarp formed a barrier, so shallow lakes could have originated, 


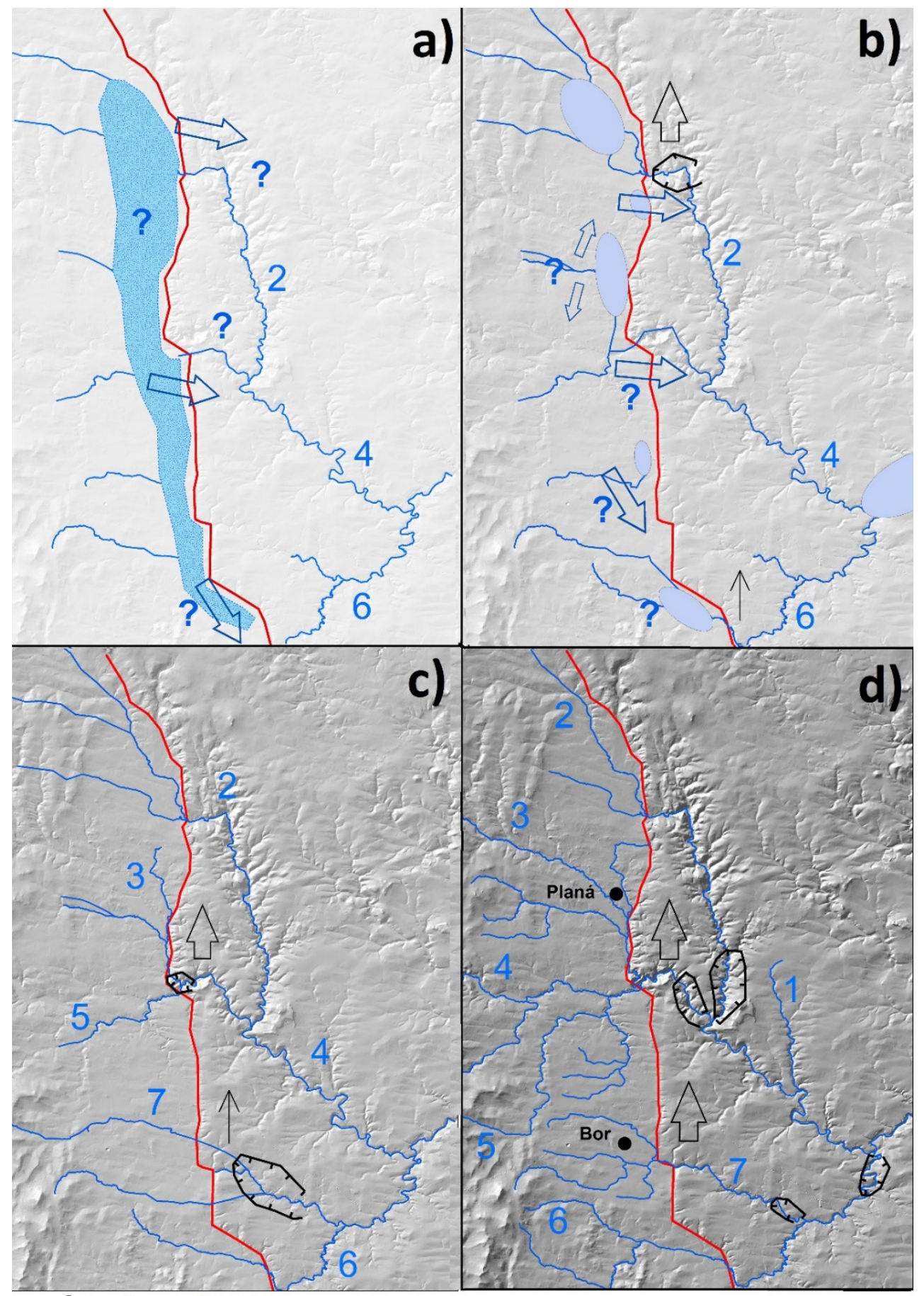

- Area of incision

- Water stream (reconstruction)

MLF (simplified)

wan Area with fluvial or lacustrine sedimentation

$\square$ Relicts of fluvial or lacustrine sedimentation

$\longrightarrow$ Possible direction of drainage

A Area of uplift along MLF $\{$ Area of intensive uplift along MLF

Fig. 14 Proposed evolution of the stream network. For a description of a particular stage (a, b, c, d) see text. Names of the present streams: 1 - Černošínský, 2 - Kosový, 3 - Hamerský, 4 - Mže, 5 - Sedlišt'ský, 6 - Úhlavka, 7 - Výrovský. 
however, drainage to the west was probably still possible by the wide, flat valleys of the predecessors of the present Mže River and Kosový stream.

Stage b) early Pliocene or late Pleistocene: The uplift along the MLF increases, gently around the current Úhlavka River and more intensively in the central part of the MLF. Due to incision caused by uplift, the Kosový stream and the Mže formed an antecedent valley. The area could also have been drained through the Úhlavka River (or its predecessor). Due to uplift, the upper parts of the Kosový, Hamerský and Úhlavka streams were diverted to the south and continued eastwards through the incised valleys.

Stage c) lower Pleistocene: The uplift along the MLF was continuing in segments $f$ and $g$ around Planá, the Mže River was further incising and developing its catchment within the Cheb-Domažlice Graben. The evolution of the Hamerský stream is not clear - it was either still going along the fault slope and not breaching it (Balatka and Sládek, 1962) or it may have begun to form its antecedent valley (preserved to the present). The Výrovský stream also breached the slope due to incision (though less intensive).

Stage d) middle Pleistocene until the Holocene: a strong final phase of uplift along the MLF in the area between Planá and Bor (segments $f$ and $g$ ). The Mže River was incising intensively and creating its deep canyon through the Plaská pahorkatina hilly land. Due to this incision, knickpoints on the Mže and Kosový streams were created near their confluence. Also, the knickpoints on the Úhlavka and Výrovský streams originated as a reaction to the incision of the trunk stream. Finally, Sedlišt'ský stream was captured by the Mže River (previously it was connected to the upper part of the Výrovský stream; see Fig. 4, Fig. 8 and Fig. 14) and the Hamerský stream breached the fault slope due to strong incision or it may have further deepened its canyon. Also, the tributaries of the Výrovský stream underwent minor changes (sharp $90^{\circ}$ bends to the west from the fault) due to the incision of the Výrovský stream (Fig. 14).

The possible timing of the above proposed events is only approximate due to a lack of dating. The fluviolacustrine sediments in the Cheb-Domažlice Graben have been palynologically dated to the Pliocene (Teodoridis et al., 2017). It is also possible to find two levels of river terraces along the Mže River (upstream from the MLF). The upper level, which follows almost the entire river, was morphostratigraphically set to "Günz" or "Pregünz". The lower level has been dated to "Riss" (Balatka and Sládek, 1962). This setting should be evaluated carefully, unfortunately more precise data are not available in the area. Based on the data, the present course of the Mže River through the fault slope of the MLF has existed at least since the lower Pleistocene, however it might have been older, draining the lakes in the Graben to the east. Based on these data, the stages are a) to the upper Pliocene, b) and $c$ ) to the lower Pleistocene and $d$ ) to the middle Pliocene (see Fig. 14). An important factor for the proposed order of the events is also the position and elevation of the depositional relicts of the Pliocene fluviolacustrine sediments (Teodoridis et al., 2017). The highest elevation known from the Cheb-Domažlice Graben is $560 \mathrm{~m}$ a.s.l. (near Mariánské Lázně). The elevation decreases towards the south: $480 \mathrm{~m}$ (Planá), $430 \mathrm{~m}$ (Úhlavka), 400 m (Horšovský Týn), see Figure 2. This situation can be a sign of the proposed drainage towards S along the graben or towards SW by the predecessor of the Úhlavka River. Some of the deposit remnants were recorded to the east from the MLF. Some of them, closer to the fault (along the Mže River), are at a higher elevation than those in the ChebDomažlice Graben (about $30 \mathrm{~m}$ height difference), which would suggest their uplift. Occurrences of deposits in the Plzen basin (further to the east, near the mouth of the Mže River) are on the same level or lower, compared to the deposits in the ChebDomažlice Graben. They can be remnants of the Pliocene Mže River (or its predecessor), whose existence has been proven by Pliocene terraces in the Plzeň basin (Balatka and Sládek, 1962). This is in accordance with the proposed uplift (or tilt) of the Plaská pahorkatina hilly land and the gradual incision of the Mže River (and tributaries) during the Pleistocene. Future work focused to sediments dating would be desirable for a final clarification of the evolution of the local stream network and the tectonic movements along the MLF.

\section{CONCLUSIONS}

The combination of morphometric methods used in this study (mountain-front sinuosity, basin asymmetry, stream longitudinal profiles, SL index) appeared to be an useful way to evaluate tectonic activity along the $150 \mathrm{~km}$ long Mariánské Lázně fault (MLF) and to compare its variable intensity. The results show that the tectonic activity has not occurred along the whole structure at the same periods, rather, particular MLF segments were active in different periods with different intensity, which is supported by the concordance of the results from the several methods used. This segmented activity of the MLF leads to significant changes in the drainage pattern in the study area, including several stream captures. Based on the scarce dated fluvial deposits, a reconstruction of the river network was suggested as was the estimated timing of its evolution from the late Pliocene until the middle Pleistocene (possibly until the Holocene). The finding from Štěpančíková et al. (2019) that the youngest tectonic activity can be located in segments $a$ and $b$ around Nový Kostel in the northwest is in concordance with morphometric results of this study and similar signs of recent (Pleistocene - Holocene) tectonic activity have been recognised in the central part of the MLF: segments $f$ and $g$ (Planá-Bor) and in the southeast, segment $i$ (Horšovský Týn). However, the final answer about the 
timing of tectonic activity should be proved by e.g. paleoseismological research and proper fluvial deposits dating.

\section{ACKNOWLEDGEMENTS}

The research was supported by the Grant Agency of the Czech Republic no. 21-29826S. The ideas were also evolved within project no. LTV20022 of the Ministry of Education, Youth and Sports. We gratefully acknowledge Richard R.H. Withers for English proof reading. We also wish to thank Jacek Szczygiel and an anonymous reviewer for their invaluable comments and suggestions, which significantly helped to improve the manuscript.

\section{REFRENCES}

Adamová, M., Čurda, J., Lochmann, Z., Majer, V., Müller, V., Opletal, M., Pošmourný, K., Tomášek, M., Veselý, J. and Volšan, V.: 2001, Set of the geological and ecological special maps of natural resources 1:50 000, Geological map. Sheet 11-41 Mariánské Lázně. Český geologický ústav, (in Czech).

Badura, J., Zuchiewicz, W., Štěpančíková, P., Przybylski, B., Kontny, B. and Cacoń., S.: 2007, The Sudetic Marginal Fault: A young morphotectonic feature at the NE margin of the Bohemian Massif, central Europe. Acta Geodyn. Geomater., 4, 4 (148), 7-29.

Balatka, B. and Kalvoda, J.: 2006, Geomorphological regionalization of the relief of Bohemia. Kartografia a.s., Praha, 79 pp., (in Czech).

Balatka, B., Kalvoda, J., Steklá, T. and Štěpančíková, P.: 2019, Morphostratigraphy of river terraces in the Eger valley (Czechia) focused on the Smrčiny Mountains, the Chebská pánev Basin and the Sokolovská pánev Basin. Acta Univ. Carol. Geogr., 54, 2, 240-259. DOI: $10.14712 / 23361980.2019 .21$

Balatka, B. and Sládek, J.: 1962, River terraces in the Czech lands. Nakladatelství československé akademie věd, Praha, 250 pp., (in Czech).

Bína, J. and Demek.: 2012, From lowlands to mountains: Geomorphological units of the Czech Republic. Academia, Praha, 343 pp., (in Czech).

Bishop, P., Hoey, T.B., Jansen, J.D. and Artza, I.L.: 2005, Knickpoint recession rate and catchment area: the case of uplifted rivers in Eastern Scotland. Earth Surf. Process Landf., 30, 6, 767-778.

DOI: $10.1002 /$ esp. 1191

Blecha, V., Fischer, T., Tábořík, P., Vilhelm, J., Klanica, R., Valenta, J. and Štěpančíková, P.: 2018, Geophysical evidence of the Eastern Marginal Fault of the Cheb Basin (Czech Republic). Stud. Geophys. Geod., 62, 660-680. DOI: 10.1007/s11200-017-0452-9

Bräuer, K., Kämpf, H., Niedermann, S. and Strauch, G.: 2005, Evidence for ascending upper mantle-derived melt beneath the Cheb basin, central Europe. Geophys. Res. Lett., 32, 8, L08303. DOI: $10.1029 / 2004 G L 022205$

Bull, W.B. and McFadden, L.D.: 1977, Tectonic geomorphology north and south of the Garlock Fault, California. In: Doehring, D.O., Ed., Geomorphology in Arid Regions: A Proceedings Volume of the 8th Annual Geomorphology Symposium, State University of New York, Binghamton, 23-24 September 1977, $115-138$.
Bull, W.: 2007, Tectonic geomorphology of mountains: A new approach to paleoseismology. Blackwell Publishing, 306 pp. DOI: 10.1002/9780470692318

Burbank, D. and Anderson, R.: 2001, Tectonic geomorphology. Blackwell Science, $273 \mathrm{pp}$. DOI: $10.1002 / 9781444345063$

Cháb, J., Breiter, K., Fatka, O., Hladil, J., Kalvoda, J., Šimůnek, Z., Štorch, P., Vašíček, Z., Zajíc, J. and Zapletal, J.: 2008, Outline of the geology of the Bohemian Massif: the Basement rocks and their Carboniferous and Permian covers. Vydavatelství ČGS, Praha, 283 pp., (in Czech).

Chlupáć, I., Brzobohatý, R., Kovanda, J. and Stráník, Z.: 2002, Geological history of the Czech Republic. Academia Praha, Praha, 436 pp., (in Czech).

Česká geologická služba - Czech Geological Survey (ČGS): 2003, Geological map of the Czech Republic, 1: 500 000, CGS, Praha, (in Czech).

Český úřad zeměměřický a katastrální (ČUZK): 2017, Digital elevation model of the Czech Republic, $5^{\text {th }}$ generation (DEM 5G). Český úřad zeměměřický a katastrální, Praha, (in Czech).

Čtyroký, J.: 1996, Evolution of the valley of the Ohře River in the Slavkovský Forest. Master thesis. Charles University, Faculty of Science, Prague, 150 pp., (in Czech).

Demek, J. and Czudek T.: 1957, Geomorphological conditions of the Jilmový Stream in the Teplá Highlands. Sborník ČSSZ, 62, 3, 193-205, (in Czech).

Fischer, T., Štěpančíková, P., Karousová, M., Tábořík, P., Flechsig, Ch. and Gaballah, M.: 2012, Imaging the Mariánské Lázně Fault (Czech Republic) by 3-D ground-penetrating radar and electric resistivity tomography. Stud. Geophys. Geod., 56, 1019-1036. DOI: $10.1007 / \mathrm{s} 11200-012-0825-\mathrm{z}$

Fischer, T., Horálek, J., Hrubcová, P., Vavryčuk, V., Bräuer, K. and Kämpf, H.: 2014, Intra-continental earthquake swarms in West-Bohemia and Vogtland: a review. Tectonophysics, 611, 1-27. DOI: $10.1016 /$ j.tecto.2013.11.001

Fischer, T., Matyska, C. and Heinicke, J.: 2017, Earthquakeenhanced permeability - evidence from carbon dioxide release following the ML 3.5 earthquake in West Bohemia. Earth Planet. Sci. Lett., 460, 60-67. DOI: 10.1016/j.epsl.2016.12.001

Gutierrez, M.: 2013, Geomorphology. London, CRC Press, $1014 \mathrm{pp}$.

Hack, J.T.: 1973, Stream-profile analysis and streamgradient index. J. Res. U.S. Geol. Surv., 1, 4, 421-429.

Halpaap, F., Paschke, M. and Bleibinhaus, F.: 2017, Shallow reflection seismic evidence of tectonic activity in the Cheb Basin, NW Bohemia. Stud. Geophys. Geod., 62, 80-101. DOI: 10.1007/s11200-016-0386-7

Jakoubková, H., Horálek, J. and Fischer, T.: 2017, 2014 mainshock-aftershock activity versus earthquake swarms in West Bohemia, Czech Republic. Pure Appl. Geophys., 175, 109-131. DOI: $10.1007 /$ s00024-017-1679-7

J.E. Purkyně University in Ústí and Labem, Ministry of the Environment of the Czech Republic (JEPU and ME): 2014, Second Military Mapping Survey of Austrian Empire, 1: 28800, [online] accessible at: http//oldmaps.geolab.cz, [15/05/2021], Laboratoř geoinformatiky Fakulta životního prostředí Univerzity J.E. Purkyně, Ústí nad Labem, (in Czech). 
Keller, E. and Pinter, N.: 2002, Active tectonics Earthquakes, Uplift and Landscape. Prentice Hall, New Jersey, $250 \mathrm{pp}$.

Mahel, M., Kodym, O. and Malkovský, M.: 1984, Tectonic map of the Czechoslovakia, 1: 500 000. Geologický ústav Dionýza Štúra, Bratislava, (in Czech).

Military Geographic and Hydrometeorologic Office (MGHO) - Ministry of Defence of the Czech Republic + GEODIS Brno s.r.o.: 2014., Historical aerial map of Czechoslovakia, 1:20000, [online] available at $\mathrm{http} / /$ : kontaminace.cenia.cz, [15/05/2021] CENIA - Česká informační agentura životního prostředí, Praha, (in Czech).

Mlčoch, B. and Konopásek, J.: 2010, Pre-Late Carboniferous geology along the contact of the Saxothuringian and Teplá-Barrandian zones in the area covered by younger sediments and volcanics (western Bohemian Massif, Czech Republic). J. Geosci., 55, 81-94. DOI: 10.3190/jgeosci.068

Mlčoch B. and Skácelová Z.: 2009, Digital elevation model of the crystalline basement of the Cheb and Sokolov Basin areas (Western Bohemia, Central Europe). Z. Geol. Wiss., 37, 3, 145-152.

Müller, V., Burda, J., Dubec, O., Hrazdíra, P., Hrkal, Z., Jinochová, J., Lochmann, Z., Majer, V., Manová, M., Mlčoch, B., Rejchrt, M., Sáňka, V., Schovánek, P., Skácelová, D., Šalanský, K. and Šantrůček, P.: 1998, Legend to the set of geological and ecological special maps of natural resources, 1: 50000 . Sheets 11 - 13 Hazlov, 11 - 14 Cheb. Český geologický ústav, (in Czech).

Pešek, J.: 1972, Tertiary sediments in the central and western Bohemia. Sborník Západočeského muzea Příroda, 6 , 56 pp., (in Czech).

Pitra P., Burg J.P. and Guiraud M.: 1999, Late Variscan strike-slip tectonics between the Tepla-

Barrandian and Moldanubian terranes (Czech Bohemian Massif): petrostructural evidence. J. Geol. Soc. London, 156, 1003-1020. DOI: 10.1144 /gsigs. 156.5 .1003

Procházková, D. and Šimůnek, P.: 1999, Regional earthquake catalogue and focal regions in central Europe. Acta Montana IRSM AS ČR, Ser. A, 13 (111), Praha, $83 \mathrm{pp}$.

Seifert, A. and Straka, J.: 1998, Geological map, 1: 50 000, sheet 11-43 Bor. ČGS, Praha, (in Czech).

Sougnez, N. and Vanacker V.: 2011, The topographic signature of Quaternary tectonic uplift in the Ardennes massif (Western Europe). Hydrol. Earth Syst. Sci., 15, 1095-1107. DOI: 10.5194/hess-15-1095-2011

Špičáková, L., Uličný, D. and Koudelková, G.: 2000, Tectonosedimentary evolution of the Cheb Basin (NW Bohemia, Czech Republic) between the Late Oligocene and Pliocene: A preliminary note. Stud. Geophys. Geod., 44, 556-580.

DOI: 10.1023/A:1021819802569

Štěpančíková, P., Stemberk, J., Vilímek, V. and Košták, B.: 2008, Neotectonic development of drainage networks in the East Sudeten Mountains and monitoring of recent fault displacements (Czech Republic). Geomorphology, 102, 68-80.

DOI: 10.1016/j.geomorph.2007.06.016
Štěpančíková, P., Fischer, T., Stemberk, J. (Jr.), Nováková, L., Hartvich, F. and Figueiredo, P.M.: 2019, Active tectonics in the Cheb Basin: youngest documented Holocene surface faulting in central Europe? Geomorphology, 327, 472-488.

DOI: 10.1016/j.geomorph.2018.11.007

Švancara, J., Havír, J. and Conrad, W.: 2008, Derived gravity field of the seismogenic upper crust of SE Germany and West Bohemia and its comparison with seismicity. Stud. Geophys. Geod., 52, 567-588. DOI: $10.1007 / \mathrm{s} 11200-008-0038-7$

Teodoridis, V., Bruch, A.A., Martinetto, E., Vassio, E., Kvaček, Z. and Stuchlik, L.: 2017, Plio-Pleistocene floras of the Vildštejn Formation in the Cheb Basin, Czech Republic - a review and a new paleoenvironmental evaluation. Palaeogeogr. Palaeoclimatol. Palaeoecol., 467, 166-190. DOI: 10.1016/j.palaeo.2015.09.038

Ulrych, J., Dostal, J., Adamovič, J., Jelínek, E., Špaček, P., Hegner, E. and Balogh, K.: 2011, Recurrent Cenozoic volcanic activity in the Bohemian Massif (Czech Republic). Lithos, 123, 133-144. DOI: $10.1016 /$ j.lithos.2010.12.008

Ulrych, J., Ackerman, L., Balogh, K., Hegner, E., Jelínek, E., Pécskay, Z. and Foltýnová, R.: 2013, PlioPleistocene basanitic and melilititic series of the Bohemian Massif: K-Ar ages, major/trace element and $\mathrm{Sr}-\mathrm{Nd}$ isotopic data. Chem. Erde-Geochem., 73, 429 450. DOI: 10.1016/j.chemer.2013.02.001

Vejnar, Z., Šalanský, K. and Skrbek, J.: 1978a, Legend to the base geological map of Czechoslovakia 1:25 000, sheet 21-214 Mířkov. Ústřední ústav geologický, Praha, (in Czech).

Vejnar, Z., Šalanský, K. and Skrbek, J.: 1978b. Legend to the base geological map of Czechoslovakia ČSSR 1:25 000, sheet 21-232 Horšovský Týn. Ústřední ústav geologický, Praha, (in Czech)

Vejnar, Z., Šalanský, K. and Skrbek, J.: 1980. Legend to the base geological map of Czechoslovakia CSSR 1:25 000, sheet 21-212 Staré Sedlo. Ústřední ústav geologický, Praha, (in Czech).

Weinlich, F.H., Bräuer, K., Kämpf, H., Strauch, G., Tesar, J. and Weise, S.M.: 1999, An active subcontinental mantle volatile system in the western Eger rift, central Europe: gas flux, isotopic ( $\mathrm{He}, \mathrm{C}$, and $\mathrm{N}$ ) and compositional fingerprints. Geochim. Cosmochim. Acta, 63, 21, 3653-3671.

DOI: $10.1016 / \mathrm{S} 0016-7037(99) 00187-8$

Willet., S.D. (ed.): 2006, Tectonics, climate and landscape evolution. The Geological Society of America, Special paper 398, $150 \mathrm{pp}$.

Wheeler, D. A.: 1979, The overall shape of longitudinal profiles of streams. In A.F. Pitty (ed.), Geographical Approaches to Fluvial Processes, Norwich GeoAbstracts, 241-260.

Zoubek, V.: 1963, Legend to the base geological map of Czechoslovakia 1: 200 000, sheet M-33-XIII Karlovy Vary, ÚÚG ČSAV, Praha, 290 pp., (in Czech). 